University of Chicago Law School

Chicago Unbound

Journal Articles

Faculty Scholarship

1992

\title{
What's Standing After Lujan? Of Citizen Suits, "Injuries," and Article III
}

Cass R. Sunstein

Follow this and additional works at: https://chicagounbound.uchicago.edu/journal_articles

Part of the Law Commons

\section{Recommended Citation}

Cass R. Sunstein, "What's Standing After Lujan? Of Citizen Suits, "Injuries," and Article III," 91 Michigan Law Review 163 (1992).

This Article is brought to you for free and open access by the Faculty Scholarship at Chicago Unbound. It has been accepted for inclusion in Journal Articles by an authorized administrator of Chicago Unbound. For more information, please contact unbound@law.uchicago.edu. 


\section{WHAT'S STANDING AFTER LUJAN? \\ OF CITIZEN SUITS, "INJURIES," \\ AND ARTICLE III $\dagger$}

Cass R. Sunstein*

INTRODUCTION .................................... 164

I. A Capsule History of Standing ............... 168

A. English and American Practice ................ 170

1. England ........................... 171

2. America, the Qui Tam Action, and Others...... 173

3. Summary............................. 177

B. The Initial Appearance of "Standing": The
Progressive and New Deal Periods ............... 179

C. The Administrative Procedure Act .............. 181

D. From "Legal Injury" to "Injury In Fact".......... 183

1. Beneficiary Suits ....................... 183

2. Conceptual Confusion, the New Deal, and the Metaphysics of "Injury" ................... 186

3. The Congressionally Created Citizen Suit....... 192

E. Redressability, Causation, and the Separation of

Powers ................................... 193

1. New Departures ......................... ' 193

2. General Trends in Administrative Law ......... 195

3. "Beneficiaries" Versus "Objects" ............. 196

II. LUJAN: DESCRIPTION AND APPRAISAL .............. 197

A. What the Court Said ....................... 197

B. Evaluation ............................ 202

1. Injury ........................... 202

2. Redressability......................... 206

3. Citizen Suits ........................... 209

C. Detour I: Justice Scalia's Conception of Standing ... 215

D. Detour II: The Citizen Suit and the Administrative State.

$\dagger$ All rights reserved.

* Karl N. Llewellyn Professor of Jurisprudence, University of Chicago Law School and Department of Political Science. A.B. 1975, J.D. 1978, Harvard. - Ed. I am grateful to Akhil Amar, David Currie, Elena Kagan, Stephen Gilles, Michael McConnell, Richard Posner, and Peter Strauss for helpful comments, and to Gabriel Gore and Richard Madris for valuable research assistance. 
E. Coda: What the Court Should Have Said ......... 222

III. The FUtURE ................................. 223

A. Easy Cases: What Lujan Permits ............. 224

B. Easy Cases: What Lujan Forecloses ............. 226

C. Injury in Fact? .......................... 226

D. Redressability ........................... 228

E. What Role Remains for the Citizen Suit? ......... 229

F. Private Defendants......................... 231

G. Cash Bounties.......................... 232

1. Private Defendants ..................... 232

2. Executive Defendants ................... 233

H. Redefined Property Rights ................... 234

Conclusion .................................... 235

\section{INTRODUCTION}

In 1983, Judge Antonin Scalia, of the U.S. Court of Appeals for the District of Columbia Circuit, published a dramatic and provocative essay on the law of standing. The thesis can be found in the title: The Doctrine of Standing As An Essential Element of the Separation of Powers. ${ }^{1}$ Only recently named a judge, and having taught administrative and constitutional law for many years, Judge Scalia called for a significant shift in the law of standing.

Judge Scalia's argument hinged on a distinction between two kinds of cases. "[W] hen an individual who is the very object of a law's requirement or prohibition seeks to challenge it, he always has standing." 2 But standing should frequently be unavailable when "the plaintiff is complaining of an agency's unlawful failure to impose a requirement or prohibition upon someone else."3 In the latter case, Judge Scalia contended that there was a serious interference with executive power. Judge Scalia concluded that in cases of the latter sort, courts should hold that Article III imposes "a limit upon even the power of Congress to convert generalized benefits into legal rights. ..."4 The Court had not addressed this important and longdisputed issue before.

In 1992, Justice Antonin Scalia wrote the dramatic opinion for the Supreme Court in Lujan v. Defenders of Wildlife, ${ }^{5}$ which significantly

1. Antonin Scalia, The Doctrine of Standing as an Essential Element of the Separation of Powers, 17 SufFolK U. L. REV. 881 (1983).

2. Id. at 894 .

3. Id.

4. Id. at 886 .

5. 112 S. Ct. 2130 (1992). 
shifts the law of standing. The opinion hinges on a distinction between two kinds of cases. "When ... the plaintiff is himself an object of the action (or forgone action) at issue . . . there is ordinarily little question" that he has standing. 6 "When, however, ... . a plaintiff's asserted injury arises from the government's allegedly unlawful regulation (or lack of regulation) of someone else, much more is needed."7 In the latter case, there is the risk of serious interference with executive power, in the form of a "transfer from the President to the courts" of "the Chief Executive's most important constitutional duty, to "take Care that the Laws be faithfully executed.' "8 Through Justice Scalia's opinion, the Court held that Article III required invalidation of an explicit congressional grant of standing to "citizens." The Court had not answered this question before. ${ }^{10}$

Lujan may well be one of the most important standing cases since World War II. Read for all it is worth, the decision invalidates the large number of statutes in which Congress has attempted to use the "citizen-suit" device as a mechanism for controlling unlawfully inadequate enforcement of the law. ${ }^{11}$ Indeed, the decision ranks among the most important in history in terms of the sheer number of federal statutes that it apparently has invalidated. ${ }^{12}$ The citizen suit has become a staple of federal environmental law in particular: nearly every major environmental statute provides for citizen standing. ${ }^{13}$ The place of the

6. 112 S. Ct. at 2137.

7. 112 S. Ct. at 2137.

8. 112 S. Ct. at 2145.

9. 112 S. Ct. at $2137-40$.

10. The apparently unanimous view of lower courts had been that a legislative grant of citizen standing was constitutional even without a showing of injury in fact. See, e.g., Evans v. Lynn, 537 F.2d 571 (2d Cir. 1976); Friends of the Earth v. Carey, 535 F.2d 165 (2d Cir. 1976); Natural Resources Defense Council, Inc. v. Train, 510 F.2d 692 (D.C. Cir. 1975); City of Chicago v. General Motors Corp., 467 F.2d 1262 (7th Cir. 1972); Citizens for a Better Envt. v. Deukmejian, 731 F. Supp. 1448 (N.D. Cal. 1990).

11. See, e.g., Toxic Substances Control Act, 15 U.S.C. \& 2619 (1988); Surface Mining Control and Reclamation Act of 1977, 30 U.S.C. $\$ 1270$ (1988); Clean Water Act of 1976, 33 U.S.C. $\S 1365$ (1988); Marine Protection, Research and Sanctuaries Act of 1972, 33 U.S.C. $\S 1415(\mathrm{~g})(1)$ (1988); Safe Drinking Water Act, 42 U.S.C. § 300j-8 (1988); Noise Control Act of 1972, 42 U.S.C. $\S 4911$ (1988); Energy Policy and Conservation Act, 42 U.S.C. $\S 6305$ (1988); Solid Waste Disposal Act, 42 U.S.C. § 6972 (1988); Clean Air Act, 42 U.S.C. § 7604 (1988 and Supp. 1990); Comprehensive Environmental Response, Compensation, and Liability Act of 1980, 42 U.S.C. $\$ 9659$ (1988); Powerplant and Industrial Fuel Use Act of 1978, 42 U.S.C. $§ 8435$ (1988); Emergency Planning and Community Right-to-Know Act of 1986, 42 U.S.C. \$ 11046(a)(1) (1988); Outer Continental Shelf Lands Act, 43 U.S.C. § 1349 (1988); Hazardous Liquid Pipeline Safety Act of 1979, 49 U.S.C. $\$ 2014$ (1988). Every major environmental statute except FIFRA authorizes a citizen suit.

12. Its chief rival in this regard is INS v. Chadha, 462 U.S. 919 (1983). See 462 U.S. at 100312 (White, J., dissenting) (appendix).

13. See supra note 11 . 
citizen in environmental and regulatory law has now been drawn into sharp question.

But the importance of Lujan does not lie only in the invalidation of the citizen suit. The decision revises the law of standing in several other ways as well. And it raises a host of new puzzles for later cases to solve.

In this article, I have two principal goals. The first is to explain why Lujan's invalidation of a congressional grant of standing is a misinterpretation of the Constitution. It is now apparently the law that Article III forbids Congress from granting standing to "citizens" to bring suit. But this view, building on an unfortunate innovation in standing law by Justice William $O$. Douglas, ${ }^{14}$ is surprisingly novel. It has no support in the text or history of Article III. It is essentially an invention of federal judges, and recent ones at that. Certainly it should not be accepted by judges who are sincerely committed to the original understanding of the Constitution and to judicial restraint. Nor should it be accepted by judges who have different approaches to constitutional interpretation.

Lujan holds that the requirement of an "injury in fact" is a limitation on congressional power; but an "injury in fact," as the Court understands it, is neither a necessary nor a sufficient condition for standing. The relevant question is instead whether the law - governing statutes, the Constitution, or federal common law - has conferred on the plaintiffs a cause of action. ${ }^{15}$ An inquiry into "injury in

14. See the discussion of Association of Data Processing Serv. Orgs. v. Camp, 397 U.S. 150 (1970), infra notes 102-13 and accompanying text.

15. In an often-quoted phrase, Justice Douglas wrote that "[g]eneralizations about standing to sue are largely worthless as such." Association of Data Processing Serv. Orgs. v. Camp, 397 U.S. 150, 151 (1970). If the analysis here is correct, this generalization is indeed largely worthless; but one generalization - that the standing issue depends on the existence of a cause of action - is not. This approach to the question of standing is also set out in Lee A. Albert, Standing to Challenge Administrative Action: An Inadequate Surrogate for Claim for Relief, 83 YaLE L.J. 425, 451-55 (1974); David P. Currie, Misunderstanding Standing, 1981 SUP. CT. REv. 41; William A. Fletcher, The Structure of Standing, 98 YALE L.J. 221 (1988); David A. Logan, Standing to Sue: A Proposed Separation of Powers Analysis, 1984 WIS. L. Rev. 37; Cass R. Sunstein, Standing and the Privatization of Public Law, 88 CoLUM. L. REv. 1432 (1988). In a similar vein, see Richard H. Fallon, Of Justiciability, Remedies, and Public Law Litigation, 59 N.Y.U. L. REv. 1 (1984). Many authorities to the same effect are collected in Fletcher, supra, at 223 n.18.

The courts have shown a discernible trend in this direction. See Air Courier Conference of America v. American Postal Workers Union, 111 S. Ct. 913 (1991); Lujan v. National Wildlife Fedn., 497 U.S. 871 (1990); Block v. Community Nutrition Inst., 467 U.S. 340 (1984). Of course one could conclude that Article III imposes limits on Congress' power to grant standing but that, short of those limits, the standing question is whether Congress or any other source of law confers a cause of action. Perhaps the law will tend in this direction even post-Lujan. See especially International Primate Protection League v. Administrators of Tulane Educ. Fund, $111 \mathrm{~S}$. Ct. 1700 (1991), where the Court said that "standing is gauged by the specific common law, statutory or constitutional claims that a party presents," and noted that standing "should be seen as a 
fact" will both allow standing where it should be denied and deny standing where it should be granted.

More fundamentally, the very notion of "injury in fact" is not merely a misinterpretation of the Administrative Procedure Act ${ }^{16}$ and Article III but also a large-scale conceptual mistake. I hope to show that the injury-in-fact requirement should be counted as a prominent contemporary version of early twentieth-century substantive due process. It uses highly contestable ideas about political theory to invalidate congressional enactments, even though the relevant constitutional text and history do not call for invalidation at all. Just like its early twentieth-century predecessor, it injects common law conceptions of harm into the Constitution. Moreover, it acts as if injury can be assessed through a purely factual inquiry, rather than one that is inevitably a product of courts' value-laden judgments and of governing legal conventions. This deep problem has been obscured by the surprising evolution of modern standing principles.

My second goal is to discuss the many new issues that will arise in the aftermath of Lujan. Under what circumstances can citizens now prove that they are not mere citizens, but people with the requisite "injury" or "personal stake"? How does Lujan affect environmental and other regulatory cases? What might Congress do to respond to the decision? These will be the key questions in the next decade. They will have considerable importance for the development of environmental law and risk regulation, and indeed for administrative and regulatory law in general.

This article is divided into three Parts. Part I briefly sets out the history of the law of standing. Here I discuss the clear acceptance of "stranger" or "citizen" suits at the founding period in both England and early America. The Lujan Court should not have taken the extraordinary step of invalidating a congressional grant of standing without investigating the relevant history.

I also describe the very recent creation of the "injury-in-fact" test. I will show that, in an exceedingly short period, a revisionist view of Article III, with no textual or historical support, has established injury in fact as a constitutional prerequisite. I also argue that, despite its apparent simplicity, the notion of injury in fact is heavily dependent on an assessment of law and is far from a law-free inquiry into facts.

Part II describes and evaluates the various holdings in the Lujan

question of substantive law, answerable by reference to the statutory and constitutional provision whose protection is invoked." $111 \mathrm{~S}$. Ct. at 1704 (citing Fletcher, supra, at 229).

16. 5 U.S.C. $\S 702$ (1988). 
case. I end the Part with two brief detours: a discussion of the role of the citizen suit in regulatory law and a general assessment of Justice Scalia's conception of Article III, as set out in his 1983 Suffolk Law Review article. The overlap between the 1992 Lujan opinion and the 1983 article is sharp and clear. The overlap makes the article a matter of considerable current interest.

Part III discusses the future of the law of standing in the wake of Lujan. Here I try to show exactly which issues are open and which closed. One of my major purposes is to explore the effect of Lujan on current regulatory cases brought by beneficiaries of regulatory statutes. I argue that in many such cases standing remains available, but that some cases brought by consumers and others are now drawn into sharp question.

In order to overcome some of the uncertainties now facing citizen suits, I recommend that Congress create a system of bounties for citizens in cases involving both private defendants and the executive branch. Even after Lujan, such a system should raise no constitutional question. Congress may also have the power both to create property rights in the benefits provided by regulatory statutes and to establish standing to vindicate those property rights. I conclude with a discussion of this intriguing possibility.

\section{A Capsule History of Standing}

The law of standing has had many remarkable twists and turns. For convenience, we might think of American law as evolving through five different eras of standing doctrine. We are now in the midst of the fifth; its contours remain indistinct. But one of its principal features is an insistence that Article III requires injury in fact, causation, and redressability - requirements unknown to our law until the 1970s. In this Part, I outline the development of standing doctrine. ${ }^{17}$

It makes sense to begin with the text of Article III, which extends "Judicial Power" to certain specified "Cases" and "Controversies."18 In the original understanding, "cases" included both civil and criminal disputes, whereas "controversies" were limited to civil disputes. ${ }^{19}$ Article III contains no explicit constitutional requirement of "standing" or "personal stake." Nor does it ever refer to "injury in fact." It does require a case or controversy, and very plausibly there is no such thing

17. Some aspects of this history are also discussed in Sunstein, supra note 15.

18. U.S. CONST. art. III, $\S 2$.

19. See Chisholm v. Georgia, 2 U.S. (2 Dall.) 419, $431-32$ (1793). 
without a cause of action. ${ }^{20}$ If we are to impose additional standing requirements, we must do so on the basis not of text but of history, both before and at the time of the framing and through judicial practice over time. ${ }^{21}$

An overview of opinions addressing the issue of standing will help illustrate the basic picture. In the history of the Supreme Court, standing has been discussed in terms of Article III on 117 occasions. ${ }^{22}$ Of those 117 occasions, 55, or nearly half, of the discussions occurred after 1985 - that is, in the past seven years. Of those 117,71 , or over two thirds, of the discussions occurred after 1980 - that is, in just over a decade. Of those 117,109 , or nearly all, of the discussions occurred since 1965. The first reference to "standing" as an Article III limitation can be found in Stark v. Wickard, ${ }^{23}$ decided in 1944. The next reference does not appear until eight years later, in Adler v. Board of Education. ${ }^{24}$ Not until the Data Processing case in $1970^{25}$ did a large number of cases emerge on the issue of standing. The explosion of judicial interest in standing as a distinct body of constitutional law is an extraordinarily recent phenomenon. ${ }^{26}$

What of "injury in fact"? No court referred to this phrase before Barlow v. Collins ${ }^{27}$ in 1970. After that year, the phrase appears in about ten cases during each succeeding five-year interval, until a leap to ten references in the brief period from 1990 to $1992 .{ }^{28}$ Thus the

20. See Akhil R. Amar, Law Story, 102 HARv. L. Rev. 688, 718 n.154 (1989) (reviewing Hart \& WeChSLER, The Federal Courts aNd the Federal System (Paul M. Bator et al eds., 3d ed. 1988)).

21. The same point is made in Scalia, supra note 1 , at 882 .

22. Search of LEXIS, Genfed library, US file (July 11, 1992). On the history of the term, see Stephen L. Winter, The Metaphor of Standing and the Problem of Self-Governance, 40 STAN. L. REV. 1371, 1418-25 (1988).

23. 321 U.S. 288 (1944).

24. 342 U.S. 485, 501 (1952) (Frankfurter, J., dissenting).

25. Association of Data Processing Serv. Orgs. v. Camp, 397 U.S. 150 (1970).

26. This evidence is crude because it is consistent with two speculations. (a) Perhaps the recency of the particular words obscures the tradition represented by the general concept. (b) Perhaps standing has become important only recently as a result of attempts to bring suit by people who would never even thought of doing so before. If (a) is true, the evidence tells us nothing. If (b) is true, the constitutional limit was always present but did not have to be often invoked until recently.

The discussion in Part I should shed light on these possibilities. For the moment, a few brief words. The history suggests that (a) is only partly true. A cause of action has traditionally been required, and this requirement is indeed imposed by Article III. But standing, as a distinct body of law, represents a genuinely new development, not a traditional one. As Part I also suggests, (b) is only partly true as well. Stranger or citizen actions are familiar to English and American law. The suit to compel nondiscretionary government action is no innovation; it is part of the old idea of mandamus. On the other hand, the modern regulatory state has furnished many more occasions for this suit than was traditional.

27. 397 U.S. 159 (1970).

28. Search of LEXIS, Genfed library, US file (July 11, 1992). 
injury-in-fact test played no role in administrative and constitutional law until the past quarter century.

To say this is not to deny that there were important antecedents for the requirement of standing. As we will soon see, there had always been a question whether the plaintiff had a cause of action, and this was indeed a matter having constitutional status. Without a cause of action, there was no case or controversy and hence no standing. This is an extremely important principle. Moreover, a handful of cases in the 1920s and 1930s relied on notions of "standing" without mentioning the word. These cases, too, are of considerable importance. But we will see that the modern understanding of standing is insufficiently self-conscious of its own novelty, even of its revisionism.

\section{A. English and American Practice}

The first period, by far the longest, ranges from the founding era to roughly 1920 . In that period, there was no separate standing doctrine at all. ${ }^{29}$ No one believed that the Constitution limited Congress' power to confer a cause of action. Instead, what we now consider to be the question of standing was answered by deciding whether Congress or any other source of law had granted the plaintiff a right to sue. ${ }^{30}$ To have standing, a litigant needed a legal right to bring suit.

The notion of injury in fact did not appear in this period. The existence of a concrete, personal interest, or an injury in fact, was neither a necessary nor a sufficient condition for a legal proceeding. People with a concrete interest could not bring suit unless the common law, or some other source of law, said so. But if a source of law conferred a right to sue, "standing" existed, entirely independently of "concrete interest" or "injury in fact." 31

Implicit in these ideas was a particular conception of Article III and a particular understanding of the relationship between Article III and standing. If neither Congress nor the common law had conferred a right to sue, no case or controversy existed. Whatever harm had occurred was not legally cognizable at all; this was a case of damnum

29. Much of the relevant history emerges from three important essays: Raoul Berger, Standing to Sue in Public Actions: Is It a Constitutional Requirement?, 78 YALE L.J. 816 (1969); Louis L. Jaffe, Standing to Secure Judicial Review: Public Actions, 74 HARV. L. REv. $1265,1269.82$ (1961); Winter, supra note 22, at 1394-425. I rely a good deal on these treatments here.

30. See Winter, supra note 22, at 1395-96 (explaining how this idea was mediated through the forms of action); supra note 15. Justice Scalia appears to have recognized this point, subject to his Article III caveats, in his 1983 article: "Standing requires . . the allegation of some particularized injury to the individual plaintiff. But legal injury is by definition no more than the violation of a legal right; and legal rights can be created by the legislature." Scalia, supra note 1, at 885.

31. See Winter, supra note 22 , at 1396. 
absque injuria. Courts had no power to hear the plaintiff's claim. There was therefore a sharp distinction between an injury on the one hand (a "harm") and a legal injury on the other. To this extent, the Article III requirement of a case or controversy did indeed constrain the category of persons who could bring suit. But the constraint had everything to do with whether the legislature or some other source of law had created a cause of action. It had nothing to do with "injury in fact."

There is no evidence of constitutional limits on the power to grant standing. In both England and America, actions by strangers, or by citizens in general, were fully permissible and indeed familiar. There is no basis for the view that the English and early American conception of adjudication forbade suits by strangers or citizens.

\section{England}

The practice in England is revealing, for it helps cast light on what the founding generation may have understood by "case or controversy." Before and at the time of the framing, the English practice was to allow strangers to have standing in the many cases involving the ancient prerogative writs. Of these writs, two of the most important were certiorari and prohibition. "The English tradition of locus standi in prohibition and certiorari is that 'a stranger' has standing, but relief in suits by strangers is discretionary." 32

The governing idea behind the writ of prohibition was that a usurpation of jurisdiction encroached on the royal prerogative. It followed that anyone could bring the writ. ${ }^{33}$ A key case was Articuloi Cleri, reported by Coke in a passage that would have been familiar to the Americans of the late eighteenth century. ${ }^{34}$ The central passage says: "And the kings courts that may award prohibitions, being informed either by the parties themselves, or by any stranger, that any court temporall or ecclesiasticall doth hold plea of that (whereof they have not jurisdiction) may lawfully prohibit the same . ..."35 No English court appears to have rejected the view that prohibition was available at the behest of strangers. ${ }^{36}$

The writ of certiorari was similarly available to citizens, and not just those with a concrete or personal interest. A case in 1724 indi-

32. Jaffe, supra note 29 , at 1274 .

33. J. M. EVANS, DE SMITH'S Judicial REView of AdMinistrative ACtion 417 (4th ed., 1980); Jaffe, supra note 29, at 1274.

34. 2 EdWARd COKE, INSTITUTES OF THE LAWS OF ENGLAND 602 (1797).

35. Id. (emphasis added).

36. See Berger, supra note 29 , at 819 ; Winter, supra note 22 , at $1394-95$. 
cated that "one who comes merely as a stranger" was entitled to discretionary judicial relief. ${ }^{37}$ Suits by strangers were also permitted under a statute allowing an information of quo warranto. ${ }^{38}$ An Eng. lish case expressly so held in the auspicious year of 1789.39

There were other English precedents for the citizen suit. In the seventeenth and eighteenth centuries, mandamus was available in England, even at the behest of strangers. ${ }^{40}$ Thus Berger writes:

From such cases a colonial lawyer might well have concluded that mandamus was capable of issuance at the suit of a stranger who sought to assert the public interest, especially because the analogy of mandamus to prohibition was early drawn, and because Coke, who had unequivocally stated the availability of prohibition to strangers, also made a massive assertion of mandamus jurisdiction. ${ }^{41}$

The mandamus action is closely related to the modern citizen suit. The purpose of the mandamus action is to require the executive branch to do what the law requires it to do. This is the same idea that underlies the citizen suit, most conspicuously in the environmental area.

Related devices in England were the informers' action and the relator action. In the informers' action, cash bounties were awarded to strangers who successfully prosecuted illegal conduct. In relator actions, suits would be brought formally in the name of the Attorney General, but at the instance of a private person, often a stranger. "[A]ny persons, though the most remote in the contemplation of the charity, may be relators ...."42 Certiorari and prohibition remain available to strangers in England today. ${ }^{43}$

The English history is sufficient to show that if we are thinking in historical terms, "the argument for a constitutional bar to strangers as complainants against unconstitutional action" is "without foundation."44 The modern injury-in-fact test, developed in the twentieth century, attempted to draw on the Westminster practice. ${ }^{45}$ But

37. Arthur v. Commissioners of Sewers, 88 Eng. Rep. 237 (K.B. 1724); see Berger, supra note 29 , at $820-21 \&$ n.29.

38. Berger, supra note 29 , at 823.

39. See Rex v. Smith, 100 Eng. Rep. 740 (K.B. 1790) (discussing Rex y. Brown); see also Berger, supra note 29, at 823 \& n.38 (noting that Rex v. Brown, decided in 1789, allowed strangers to enforce acts of Parliament, as such acts were of interest to all in "the kingdom").

40. Berger, supra note 29 , at 824-25.

41. Id. (footnotes omitted).

42. Attorney Gen. v. Bucknall, 26 Eng. Rep. 600 (Ch. 1741).

43. Berger, supra note 29 , at 823.

44. Id. at 827.

45. Thus Justice Frankfurter wrote:

[A] court will not decide a question unless the nature of the action challenged, the kind of injury inflicted, and the relationship between the parties are such that judicial determination 
enough has been said to show that this is a historical blunder.

\section{America, the Qui Tam Action, and Others}

There is relatively little explicit material on the Framers' conception of "case or controversy." 46 Certainly there is no direct evidence that injury in fact or concrete interest was intended to be a constitutional prerequisite under Article III. There is no reason to think that the Framers sought to limit Congress' power to create "cases" or "controversies" by conferring causes of action. 47 To understand what the Americans understood, it is useful to consult the early American practice, looking at the state and federal levels.

If we look at the practice in state courts, we will find no reason to think that the American practice was more restrictive than that in England. Several state cases built explicitly on the English practice. For example, a South Carolina court issued a writ of prohibition at the behest of a stranger. ${ }^{48}$ A New Jersey case in 1794 established stranger jurisdiction in certiorari, effectively allowing a citizen action. ${ }^{49}$ Another New Jersey case issued a writ of certiorari on behalf of a citizen and expressly rejected the view that the "court ought not to award a certiorari on the mere prayer of an individual, unless he will previously lay some cause before them tending to show that he is or may be affected by the operation of the by-law . . .."so

Other cases in the first century of the republic suggested the same view. ${ }^{51}$ Thus Louis Jaffe summarized his historical survey with the

is consonant with what was, generally speaking, the business of the Colonial courts and the courts of Westminster when the Constitution was framed.

Joint Anti-Fascist Refugee Comm. v. Morsath, 341 U.S. 123, 150 (1951) (Frankfurter, J., concurring).

46. Most of it is collected in 4 Philip B. KurLand \& RalPh LeRner, The Founders' CONSTITUTION 212-373 (1987).

47. Cf. Marbury v. Madison, 5 U.S. (1 Cranch) 137, 163-64 (1803) (exploring whether the right to a commission is something which the laws of the United States cannot enforce:

In pursuing this inquiry, the first question which presents itself, is, whether this can be arranged with that class of cases which come under the description of damnun absque injuria - a loss without an injury.

This description of cases never has been considered, and it is believed never can be considered, as comprehending offices of trust, of honor or of profit. The office of justice of peace in the district of Columbia is such an office; it is therefore worthy of the attention and guardianship of the laws. It has received that attention and guardianship. It has been created by special act of congress, and has been secured, so far as the laws can give security to the person appointed to fill it, for five years. It is not then on account of the worthlessness of the thing pursued, that the injured party can be alleged to be without remedy.).

48. Zylstra v. Corporation of Charleston, 1 S.C.L. (1 Bay) 382, 398 (1794).

49. State v. Justices of Middlesex, 1 N.J.L. 283, 294 (1794).

50. State v. Corporation of New Brunswick, 1 N.J.L. 450, 451 (1795).

51. See Jaffe, supra note 29, at 1276-79. Jaffe notes that this position has survived to the present day. "The considerable weight of authority now supports the citizen-mandamus suit." Id. at 1276 \& n. 44 . 
suggestion that "the public action - an action brought by a private person primarily to vindicate the public interest in the enforcement of public obligations - has long been a feature of our English and American law." 52

At the national level, there is no clear American tradition of reliance on the prerogative writs. According to the Supreme Court's interpretation of the All Writs Act, ${ }^{53}$ Congress did not choose explicitly to create general mandamus, prohibition, or certiorari jurisdiction, though there were particular statutory and common law cases involv. ing the writs, and it seems clear that their limited use was a matter of legislative discretion rather than constitutional command. ${ }^{54}$ There are, however, revealing early precedents for the citizen suit at the national level. The writ of prohibition to restrain an allegedly unconstitutional tax was treated as a constitutional case in a relatively early decision of the Marshall Court, 55 and in 1875 the Supreme Court allowed a petition for mandamus at the behest of what it treated as citizens. In Union Pacific Railroad v. Hall, ${ }^{56}$ merchants brought suit to require a federally chartered railroad to create a certain railroad line. They invoked a general mandamus statute "to compel the Union $\mathrm{Pa}$ cific Railroad Company to operate its road as required by law."57 The Court said that the merchants were attempting to enforce "a duty to the public generally" and that they "had no interest other than such as belonged to others." 58 Nonetheless, the Supreme Court allowed the action to go forward.

Moreover, the early Congress was active as well. I believe that Congress supplied two precedents - the qui tam action and the informers' action - that operate as a powerful affirmative argument

52. Louis L. Jaffe, Standing to Secure Judicial Review: Private Actions, 75 HARV. L. Rev. 255,302 (1961). After the founding period, the American law took on a predictably complex and somewhat exotic form, with rules of its own. See Frank Goodnow, The Principles of ADMINISTRATIVE LAW OF THE UNITED STATES 418-41 (1905). For the modern rules, see 2 Chester J. Antieau, The Practice of Extraordinary Remedies (1987), discussing prohibition, quo warranto, and certiorari. Although many modern American courts generally require a personal stake of some kind, this requirement is far from universal. See, e.g., id. at 622-24 (describing citizen and taxpayer standing in Georgia, Hawaii, and New Jersey).

53. 28 U.S.C. $\S 1651$ (1988).

54. The Supreme Court denied general mandamus jurisdiction, but did so on the theory that Congress had not chosen to act, not that there was any Article III issue. Thus the Court concluded that the Judiciary Act of 1789, ch. 20, § 14, 1 Stat. 73, 811-82 (1848), did not vest general mandamus power in the federal courts. See McIntire v. Wood, 11 U.S. (7 Cranch) 504, 505-06 (1813); see also Kendall v. United States, 37 U.S. (12 Pet.) 524, 569, 577-79 (1838).

55. Weston v. City Council of Charleston, 27 U.S. (2 Pet.) 171 (1829).

56. 91 U.S. 343 (1875). For an especially good discussion of this case, see Winter, supra note 22 , at 1404-05.

57. 91 U.S. at 343.

58. 91 U.S. at 354. 
against the view that Article III bars "stranger" or "citizen" actions once these have been congressionally authorized.

The most important development was the widespread early congressional creation of the qui tam action. The purpose of this action is to give citizens a right to bring civil suits to help in the enforcement of the federal criminal law. Under the qui tam action, a citizen - who might well be a stranger - is permitted to bring suits against offenders of the law. Qui tam actions are familiar to American law. "Statutes providing for actions by a common informer, who himself has no interest whatever in the controversy other than that given by statute, have been in existence for hundreds of years in England, and in this country ever since the foundation of our Government."59 In the first decade of the nation's existence, Congress created a number of qui tam actions. ${ }^{60}$ Explicit qui tam provisions were allowed under many statutes, including those criminalizing the import of liquor without paying duties, ${ }^{61}$ prohibiting certain trade with Indian tribes, ${ }^{62}$ criminalizing failure to comply with certain postal requirements, ${ }^{63}$ and criminalizing slave trade with foreign nations. ${ }^{64}$

The qui tam action was accompanied by the informers' action. Through this action, people can bring suit to enforce public duties; successful plaintiffs keep a share of the resulting damages or fines. In the states, this action had become familiar in the early stages of American history. Notably, the informers' action was available against both private defendants and public officials. ${ }^{65}$ Early Congresses created at least two informers' actions to assist in the enforcement of federal law. The first of these operated not only against private violators but against executive officials as well. ${ }^{66}$ "Suits by those without personal injury who were acting as representatives of others were not viewed as raising constitutional problems under article III."67

For present purposes, what is especially revealing is that there is

59. United States ex rel. Marcus v. Hess, 317 U.S. 537, 541 n.4 (1943) (quoting Marvin v. Trout, 199 U.S. 212, 225 (1905)).

60. There is a valuable discussion in Harold J. Krent, Executive Control Over Criminal Law Enforcement: Some Lessons From History, 38 AM. U. L. REv. 275, 296-303 (1989), and I draw on that discussion here. See also Evan Caminker, The Constitutionality of Qui Tam Actions, 99 YALE L.J. 341 (1989).

61. Act of Mar. 3, 1791, ch. 15, § 44, 1 Stat. 199, 209.

62. Act of May 19, 1796, ch. 30, $\S 18,1$ Stat. $469,474$.

63. Act. of Feb. 20, 1792, ch. 7, § 25, 1 Stat. 232, 239.

64. Act of Mar. 22, 1794, ch. 11, § 2, 1 Stat. 347, 349.

65. See Winter, supra note 22 , at 1406-09 \& nn.189-91.

66. See Act of July 31, 1989, ch. 5, § 29, 1 Stat. 29, 45; see also Act of May 8, 1792, ch. 36, $\S 5$, 1 Stat. 275, 277-78.

67. Winter, supra note 22 , at 1409. 
no evidence that anyone at the time of the framing believed that a qui tam action or informers' action produced a constitutional doubt. No one thought to suggest that the "case or controversy" requirement placed serious constraints on what was, in essence, a citizen suit. This fact provides extremely powerful evidence that Article III did not impose constraints on Congress' power to grant standing to strangers.

There are two possible differences between the qui tam and informers' actions on the one hand and the modern citizen suit on the other. First, the former are usually brought against a private defendant. By contrast, the government is often the defendant in the citizen suit, as indeed it was in Lujan itself. If the requirement of injury is to be read in light of constitutional provisions relating to executive power, ${ }^{68}$ then the existence of the qui tam and informers' actions may not be decisive as against the claim that citizen or stranger suits are constitutionally forbidden.

Second, the victor in a qui tam action is ordinarily entitled to recover money to be paid to himself, to the United States, or to both. The victor in an informers' action also receives some financial benefit. By contrast, the victor in a citizen action does not recover money. For this reason it is not completely odd to think that, as originally understood, the Constitution permitted stranger actions only if dollars were to change hands.

These are not entirely implausible distinctions. But if they are set out as part of an argument that Article III forbids the citizen suit, they do make for quite a stretch. Most important, the informers' action was available against public as well as private defendants at the state and federal levels. It cannot be distinguished on the ground that it operated only against private defendants. Nor should it matter that money does not change hands. The history suggests that the bounty is designed to offer an incentive, not to create an injury where none existed before. A declaratory judgment or an injunction serves the same purposes as a victorious suit in a qui tam or informers' action. Indeed, mandamus suits did not involve money at all, and these too were accepted during the early period. ${ }^{69}$

More generally, if the stranger suit was thought constitutionally problematic, in all probability some constitutional concern would have been voiced about the qui tam action or the informers' action. The absence of any concern about these actions makes it exceedingly unlikely that the case or controversy requirement was believed to place

68. See infra text accompanying notes 145-47.

69. See supra notes 53-58 and accompanying text. 
any constraints on Congress' ability to grant causes of action to strangers. ${ }^{70}$

The Constitution may require courts to impose greater constraints on standing when the executive is the defendant."1 But if an "injury in fact" is required by Article III, it should not matter a great deal whether the defendant is public or private. Hence the qui tam and informers' actions do seem to be powerful evidence against the claim that an injury in fact is an Article III requirement.

\section{Summary}

The discussion thus far has shown that early English and American practices give no support to the view that the Constitution limits Congress' power to create standing. The relevant practices suggest not that everyone has standing, nor that Article III allows standing for all injuries, but instead something far simpler and less exotic: people have standing if the law has granted them a right to bring suit. There is no authority to the contrary before the twentieth century, and, indeed, I think that there is no such authority before World War II. ${ }^{72}$

A general picture emerges from the words of the great administrative law teacher Frank Goodnow, writing in 1905. Goodnow's extensive treatise has no discussion of standing, then a foreign concept; but it does deal with the prerogative writs in America. Describing what had come to be the American practice, Goodnow wrote:

The purpose of the writs is twofold. In the first place, they are issued mainly with the intention of protecting private rights; in the second place, some of them may be made use of also for the purpose of the maintenance of the law regardless of the fact whether in the particular case a private right is attacked or not. Thus in the case of the certiorari it has been held that this writ may not be made use of simply for the maintenance of the law, that no one may apply for it unless he has some particular interest in its issue which is greater than that possessed by the ordinary citizen. The courts, however, have held with regard to the quo warranto that it may be issued on the demand of any citizen of responsibility; and the better rule would seem to be that in matters of public concern any citizen or taxpayer may apply for the mandamus. ${ }^{73}$

In this light, is it even possible to argue that the case or controversy requirement forbids the citizen action? Perhaps the English cases are not decisive, since the case-or-controversy requirement was

70. The notion of "stranger" is in fact problematic in this context, for the cause of action makes the litigant the holder of a kind of property right. See infra notes 130-32 and accompanying text.

71. The point is discussed infra text accompanying notes $145-47$.

72. See supra notes 23-31 and accompanying text.

73. GoodNow, supra note 52, at 431-32 (emphasis added) (footnotes omitted). 
not present in English law. That requirement might even be seen as a check on certain suits cognizable in England. Nor is the American practice completely unambiguous. The prerogative writs were not generally available at the behest of strangers in the federal courts. As noted, the qui tam action operated against private persons, and money would always change hands. It might therefore remain possible to argue that Article III indeed requires a "personal stake" or an "injury in fact" because, in the United States, federal courts were not traditionally given jurisdiction in pure citizen suits.

The history does not completely foreclose this argument, but it does make the argument seem far-fetched. There is absolutely no affirmative evidence that Article III was intended to limit congressional power to create standing. There is no affirmative evidence of a requirement of a "personal stake" or an "injury in fact" - beyond the genuine requirement that some source of law confer a cause of action. Nor is there reason to believe that the case-or-controversy requirement was designed to draw sharper limits than existed in English law. The general unavailability of the prerogative writs in federal court was a matter of legislative discretion, not constitutional compulsion. ${ }^{74}$ It is at the very least highly suggestive that no one seemed to think that the qui tam or informers' action raised an Article III issue. In light of all this, the claim that Article III bars citizen standing - once Congress has created it - seems most adventurous as a matter of history.

It would be possible to respond that particular historical understandings are not always binding in constitutional law. Segregation is unconstitutional even if the framers did not intend to abolish it; ${ }^{75}$ in the Due Process Clause, the meaning of "liberty" changes over time;" the Contracts Clause has been understood to be far narrower than originally conceived. ${ }^{77}$ Perhaps Article III should be treated the same way; perhaps we should not be bound by the framers' particular conception of its meaning.

The general point about constitutional interpretation seems correct, but it does not justify the view that Article III prohibits Congress from granting standing to citizens. When the specific understandings are not binding, it is because the framers are taken to have set out a general principle capable of change over time, or because changed circumstances call for a departure from historically specific understand-

74. See supra note 54.

75. See Brown v. Board of Educ., 347 U.S. 483 (1954).

76. See Goldberg v. Kelly, 397 U.S. 254 (1970).

77. See Home Bldg. \& Loan Assn. v. Blaisdell, 290 U.S. 398 (1934). 
ings. ${ }^{78}$ In Article III, the general principle is that a case cannot exist unless some source of law creates a cause of action. It is hard to understand why this principle should be abandoned in the context of a citizen suit. ${ }^{79}$

\section{B. The Initial Appearance of "Standing": The Progressive and New Deal Periods}

The second stage of standing law occurred in the early parts of this century. It was here that "standing" began to make a modest initial emergence as a discrete body of doctrine. To understand this development, a little background is in order.

The preliminary development of standing doctrine should be understood as part and parcel of the heated struggle, in the 1920s and 1930 s, within the country and the courts about the constitutional legitimacy of the emerging regulatory state. Courts frequently invoked the Constitution as a barrier to regulatory law. ${ }^{80}$ Justices Brandeis and Frankfurter were, in their somewhat different periods, the leading exponents of the view that courts should defer to the outcomes of democratic processes.

In this light, it should come as no surprise that the principal early architects of what we now consider standing limits were Justices Brandeis and Frankfurter. ${ }^{81}$ Their goal was to insulate progressive and New Deal legislation from frequent judicial attack. Attempting to counter the aggressive Supreme Court of the period, Justices Brandeis and Frankfurter helped develop a range of devices designed to limit the occasions for judicial intervention into democratic processes.

78. Brown exemplifies both these points. See Brown, 347 U.S. at 483.

79. I do not contend that there are no limits to Congress' power to decide what is a "case" or "controversy." In all likelihood, for example, Congress is barred from overcoming the ban on advisory opinions. See Geoffrey R. STONE ET AL., Constrtutional LAW 86 (2d ed. 1991). This ban is a plausible inference from the "Opinions in Writing" Clause, which allows the President to require opinions from heads of departments, but not from judges. U.S. CoNST. art. II, $\$ 2$, cl. 1. Moreover, the notion of a "case," as historically understood, excludes the judicial provision of advice at the behest of public officials. Outside of the distinctive area of standing, then, there are barriers to Congress' power to create a "case" where one did not exist before. In very rare cases, there may even be barriers to the congressional conferral of standing for separation-of-powers reasons. Consider, for example, a grant of standing to all members of Congress to challenge all executive action. I do not deal with such exotic examples here. See also Hayburn's Case, 2 U.S. (2 Dall.) 409 (1792) (refusing to adjudicate case where judicial decision is subject to executive suspension and legislative revision).

80. See, e.g., Lochner v. New York, 198 U.S. 45 (1905); see also LAURENCE H. TRIBE, AMERICAN CONSTITUTIONAL LAW 573-74 nn. 23-25 (2d ed. 1988) (collecting cases). The connection between the New Deal and the development of standing doctrine is traced in illuminating detail in Winter, supra note 22, at 1452-57, and briefly discussed in Sunstein, supra note 15, at 1437-38.

81. See Winter, supra note 22, at 1443-52. 
In the key cases, they repudiated constitutional attacks on legislative and administrative action by invoking justiciability doctrines. ${ }^{82}$ Prominent among these doctrines was the requirement of what we now think of as standing. ${ }^{83}$ The crucial cases involved efforts by citizens at large to invoke the Constitution to invalidate democratic outcomes. ${ }^{84}$ In such cases, the Court held that there was no personal stake for the invocation of judicial power.

How are we to understand these cases? We might begin by asking whether there was any source of a cause of action. In each case, no common law right was at stake. In addition, no statute created a right to bring suit. Finally, it seemed implausible to suggest, in these cases, that the relevant constitutional provision created a private right of action. The very notion that private rights of action - or standing could be created by constitutional provisions was many years away. ${ }^{85}$ Even if some constitutional provisions created private rights, it seemed hard to accept the view that provisions in these cases did so, because the relevant duties could not be individuated and seemed to run to the public at large. I take up this matter below. ${ }^{86}$

The development of standing limitations in the early part of the twentieth century was indeed a novelty, in the sense that no separate body of standing law existed before this period. Notably, the relevant opinions did not even refer to the word standing. But we might well see the Brandeis-Frankfurter innovations as broadly compatible with preexisting law. For the most part, their opinions can be read to hold that no one has a right to sue unless some law has conferred a right to do so. In the cases in which the cause of action was denied, no such right had been conferred. This was the key point in the relevant opinions. ${ }^{87}$

82. See Switchmen's Union v. National Mediation Bd., 320 U.S. 297 (1943) (reviewability); FCC v. CBS, 311 U.S. 132 (1940) (same); Myers v. Bethlehem Shipbuilding Corp., 303 U.S. 41 (1938) (reviewability and ripeness).

83. See, e.g., Joint Anti-Fascist Refugee Comm. v. McGrath, 341 U.S. 123, 154-55 (1951) (Frankfurter, J., concurring); Ashwander v. TVA, 297 U.S. 288, 341-45 (1936) (Brandeis, J., concurring); Fairchild v. Hughes, 258 U.S. 126, 129-30 (1922); see also Wilson v. Shaw, 204 U.S. 24, 30-31 (1907) (refusing to enjoin payments by U.S. government for construction of Panama Canal as plaintiff demonstrated no interest and such relief "would be an exercise of judicial power which ... is novel and extraordinary"). It is especially notable that Justice Brandeis' great opinion in Ashwander - the modern source of justiciability doctrine - does not refer to Article III at all. See Winter, supra note 22, at 1424.

84. See Massachusetts v. Mellon, 262 U.S. 447, $479-80$ (1923); Winter, supra note 22, at 1424; infra text accompanying notes 212-14.

85. See Bivins v. Six Unknown Named Agents, 403 U.S. 388 (1971).

86. See infra text accompanying notes 215-18.

87. See infra text accompanying notes 212-21. Some of the cases, most prominently Mellon, 262 U.S. at 486-88, did express doubt about citizen or taxpayer standing, though not in the context of an express congressional grant. 
As noted above, the requirement of a cause of action is indeed a command both of Article III and of tradition. ${ }^{88}$ The relevant denials of standing were therefore properly based on the plaintiffs' inability to find a law that entitled them to sue. Thus the Supreme Court could write as late as 1939 that, to have standing, a plaintiff must have a "legal right - one of property, one arising out of contract, one protected against tortious invasion, or one founded on a statute which confers a privilege."89

\section{The Administrative Procedure Act}

The third period in the development of standing consists of the enactment and interpretation of the Administrative Procedure Act (APA) in 1946.90 The relevant provision of the APA was an effort to codify the developing body of judge-made standing law: "A person suffering legal wrong because of agency action, or adversely affected or aggrieved by agency action within the meaning of a relevant statute, is entitled to judicial review thereof." 91 This apparently cryptic phrase was actually designed to recognize standing in three straightforward categories of cases. All three categories had become well-established under previous law. ${ }^{92}$

First, people could obtain standing by showing that they suffered a "legal wrong" because a common law interest was at stake. An invasion of a common law interest would certainly qualify as a legal wrong. Courts presumed that anyone who could show such an invasion would be entitled to bring suit. This idea had constitutional foundations, to the extent that a foreclosure of standing to people with common law interests might raise problems under the Due Process Clause or Article III. ${ }^{93}$

Second, plaintiffs could show that they suffered a legal wrong within the meaning of APA by demonstrating that their statutory in-

88. See supra text accompanying notes $30-31$.

89. Tennessee Elec. Power Co. v. TVA, 306 U.S. 118, 137-38 (1939).

90. Administrative Procedure Act, ch. 423,60 Stat. 237 (1946) (codified at 5 U.S.C. $\S \S 551-$ 59, 701-06 (1988)).

91. 5 U.S.C. $\S 702$ (1988).

92. See United States Dept. of Justice, Attorney General's Manual on the AdMINISTRATIVE ProcedURE ACr (1947): "The Attorney General advised the Senate Committee on the Judiciary of his understanding that section 10(a) was a restatement of existing law. . . This construction of section 10(a) was not questioned or contradicted in the legislative history." Id. at 96 (footnote omitted); see also Richard Stewart, The Reformation of American Administrative Law, 88 HARV. L. REV. 1667, 1723-47 (1975); Sunstein, supra note 15, at 1438-40.

93. See Yakus v. United States, 321 U.S. 414, $431-35$ (1944) (discussing due process issue but finding no violation as statute in question provided reasonable opportunity to challenge its validity); Crowell v. Benson, 285 U.S. 22, 40-41 (1932) (finding no due process or Article III violation as remedies provided in statute approximated probable judicial damages). 
terests were at stake. For example, if the interest of a litigant in competition on equal terms was a relevant factor under the governing statute - if the agency was required to take that factor into account - the litigant would have standing to bring suit to vindicate its interest. Congress need not have expressly conferred standing on the plaintiff; under the APA, the mere existence of an interest protected by statute was sufficient. ${ }^{94}$ The APA's framers paid little attention to the question how far this approach would extend standing to beneficiaries and competitors, though it seems clear that standing was not merely contemplated for objects. 95

The third category did not involve legal wrong at all. People could bring suit if they could show that "a relevant statute" - a statute other than the APA - granted them standing by providing that people "adversely affected or aggrieved" were entitled to bring suit. In this way, the APA recognized that Congress had allowed people to have causes of action, and hence standing, even if their interests were not entitled to consideration by the relevant agency. Such people could act as "private attorneys general." This had already occurred under the Federal Communications Act. ${ }^{96}$ The APA thus provided for congressional authorization of actions by people lacking legal injuries.

This, then, was the APA framework: standing for people whose common law or statutory interests were at stake, as well as for people expressly authorized to bring suit under statutes other than the APA. Under the APA, there was considerable continuity with previous law, in the sense that the principal question, for purposes of standing, was whether the law had conferred a cause of action. Injury in fact was neither a necessary nor a sufficient element.

94. See The Chicago Junction Case, 264 U.S. 258, 266-69 (1924); SENATE COMM. ON THE Judiciary, Administrative Procedure Act: Legislative History, S. Doc. No. 248 , 79th Cong., 2d Sess. 276 (1946): "The phrase 'legal wrong' ... means that something more than mere adverse personal effect must be shown in order to prevail - that is, that the adverse effect must be an illegal effect."

I will not discuss here the question how to interpret statutes that are ambiguous on the existence of a private cause of action. For present purposes, the key point is that the APA did not require an explicit grant, but instead inferred a cause of action (standing) from the existence of an interest that the agency was entitled to consider.

95. See supra text accompanying notes 90-92; see also Sunstein, supra note 15 , at 1440-51 (discussing the APA and beneficiary standing).

96. See 47 U.S.C. $§ 402(b)(6)$ (1988); FCC v. Sanders Bros. Radio Station, 309 U.S. 470, 47677 (1940). 


\section{From "Legal Injury" to "Injury in Fact"}

The fourth stage of standing law spanned from the early 1960s until about 1975. It included several dramatic new departures.

\section{Beneficiary Suits}

The shift in this fourth period began when courts interpreted the "legal wrong" test to allow many people affected by government decisions - including beneficiaries of regulatory programs - to bring suit to challenge government action. For example, courts concluded that displaced urban residents, listeners of radio stations, and users of the environment could proceed against the government to redress an agency's legally insufficient regulatory protection. 97 To understand these developments, a little background is again in order.

In the 1960s and 1970s, observers of regulatory law claimed that congressional purposes could be undermined not merely by excessive regulation, but also by insufficient regulation or agency hostility to statutory programs. ${ }^{98}$ If conformity to law was a goal of administrative law, there was no reason to distinguish between the beneficiaries and the objects of regulation. Suits brought by beneficiaries might well serve to promote agency fidelity to legislative enactments.

In the same period, there was also a good deal of empirical literature suggesting that agencies were sometimes subject to sustained

97. See Norwalk CORE v. Norwalk Redev. Agency, 395 F.2d 920, 932-37 (2d Cir. 1968); Office of Communication of the United Church of Christ v. FCC, 359 F.2d 994, 1000-06 (D.C. Cir. 1967); Scenic Hudson Preservation Conf. v. FPC, 354 F.2d 608, 615-17 (2d Cir. 1965), cert. denied, 384 U.S. 941 (1966). Then-Judge Burger wrote, in an influential passage:

The theory that the [FCC] can always effectively represent the listener interests in a renewal proceeding without the aid and participation of legitimate listener representatives fulfilling the role of private attorneys general is one of those assumptions we collectively try to work with so long as they are reasonably adequate. When it becomes clear, as it does to us now, that it is no longer a valid assumption which stands up under the realities of actual experience, neither we nor the Commission can continue to rely on it. The gradual expansion and evolution of concepts of standing in administrative law attests that experience rather than logic or fixed rules has been accepted as the guide.

United Church of Christ, 359 F.2d at 1003-04.

The general idea that courts might review unlawful inaction was hardly inconsistent with the APA as originally understood. See U.S. ATtORNEY GENERAL's COMMITTEE ON ADMINISTRAtive Procedure, Administrative Procedure in Government Agencies, S. Doc. No. 8, 77th Cong., 1st Sess. (1941):

[T] he problem of whether the administrator's refusal to take action is reviewable still remains. . . . In some instances review may be unavailing because the determination of whether or not action should be taken in the circumstances may have been committed to the exclusive judgment of the administrator as to the public interest and convenience. But if the denial is based on an erroneous interpretation of law, judicial review is available to remove at least that barrier.

Id. at 86 (emphasis added).

98. Much of this is catalogued in JAMES FreEDMAN, CRISIS AND LegitimacY (1976) and Stewart, supra note 92 , at 1682-87. 
political pressure from regulated industries. ${ }^{99}$ The result was agency "capture." Through this process, statutory enactments could be defeated during implementation, principally as a result of the continuous exercise of power by well-organized private groups, or "factions." Collective action problems faced by the often-diffuse members of the beneficiary class made it hard for them to exert the same kind of continuous influence on government. Just as unorganized interests would be at a systemic disadvantage in economic ordering, so they would face serious problems in the political process. Government failure would therefore mimic market failure.

This account was extremely influential in the 1960s and 1970s, and it has continuing popularity today. 100 But it should not be overdrawn. The empirical literature did not establish a systemic risk of administrative abdication, and it did not demonstrate that regulated industries are always in a better position to influence government than beneficiaries. Sometimes the opposite seemed true. ${ }^{101}$ But the empirical literature was sufficient to cast into severe doubt the idea that regulatory objects, and not beneficiaries, should have access to judicial review. That idea seemed to stem from partisan considerations or judicial hostility to regulatory programs enacted by Congress; it did not appear to have any better pedigree. In view of the empirical evidence, it seemed positively perverse to grant standing to objects and not to beneficiaries. Thus it was that the legal injury test came, quite naturally and plausibly, to be read to allow standing for beneficiaries, who often faced statutory harm - "legal injury" — by virtue of inadequate regulatory action.

These modest expansions in standing were entirely compatible with the language and framework of the APA. They built on the "legal wrong" idea to grant standing to many individuals and groups intended to be benefited by statutory enactments. It was fully reasonable to think that the beneficiaries of regulation suffered a legal injury when government failed to protect their legal interests. But a huge

99. Mancur Olson, The logic of Collective Action: Public Good and the TheORY OF GROUPS (1971), is the best-known general overview. See also Russell Hardin, ColLECTIVE ACTION (1982). For an important study addressing the "capture" phenomenon, see MARVIN H. BERNSTEIN, REgulating Business By INDEPENDENT COMMISSION (1955). For general discussion, see The Politics of Regulation (James Q. Wilson ed., 1980); Paul J. QUIRK, INDUSTRY INFLUENCE IN FEDERAL REgULATORY AGENCIES (1981); KAYE LEHMAN SChLOZMAN \& JaMES T. TIERNEY, ORganized INTERESTS AND AMERICAN DEMOCRACY (1980).

100. See, e.g., Alan B. Morrison, OMB Interference with Agency Rulemaking: The Wrong Way to Write a Regulation, 99 HARV. L. REV. 1059 (1986).

101. See William A. Niskanen, JR., Bureaucracy and Representative GovernMENT 18-20 (1971). 
and far less justified conceptual break occurred in Justice William $\mathbf{O}$. Douglas' opinion for the Court in Association of Data Processing Organizations v. Camp, ${ }^{102}$ which provides the basic underpinnings for the modern law of standing. In Data Processing, the Court essentially jettisoned the entire framework of the APA, even as it purported to interpret that very statute.

In a remarkably sloppy opinion, the Data Processing Court concluded that a plaintiff no longer needed to show a "legal interest" or "legal injury" to establish standing. That test "goes to the merits. The question of standing is different." 103 Instead of a careful examination of the governing law to see if Congress had created a legal interest, the standing inquiry would be a simple one barely related to the underlying law. Henceforth the issue would turn on facts, not on law.

In the new test, standing existed for anyone who could show (a) "injury in fact, economic or otherwise" 104 and (b) injury "arguably ... within the zone of interests"105 of the regulatory statute. The zone-ofinterests test was intended to be exceptionally lenient ${ }^{106}$ and for present purposes may be put to one side. ${ }^{107}$ The result of Data Processing was thus an entirely new focus for determining the class of persons entitled to bring suit. The Court appeared fully to endorse the $1960 \mathrm{~s}$ expansions in the legal interest test; under its new test, beneficiaries of regulatory programs would generally have standing. But they no longer were required to show any legal interest. Instead they had to show an injury in fact.

One might well ask: What was the source of the injury-in-fact test? Did the Supreme Court just make it up? The answer is basically yes. 108 The concept of "injury in fact" first arose in a 1958 treatise by

102. 397 U.S. 150 (1970).

103. 397 U.S. at 153.

104. 397 U.S. at 152.

105. 397 U.S. at 156.

106. See Data Processing, 397 U.S. at 154-55 (noting instances where standing exists).

107. There has, however, been a recent rebirth in the zone-of-interests test - unintended in Data Processing, but perhaps presaging a partial return to the legal interest test. Thus the first Supreme Court case denying standing on zone-of-interest grounds came in 1991. See Air Courier Conference of Am. v. American Postal Workers Union, 111 S. Ct. 913 (1991). If the analysis in this essay is right, this development should be enthusiastically welcomed as a return to the correct understanding of the APA and Article III.

108. Here I agree entirely with Justice Scalia. See Scalia, supra note 1, at 887-89. Others have also rejected the conclusion that the APA requires an injury in fact. The most famous is Louis L. Jaffe, Standing Again, 84 HARV. L. REV. 633, 636 (1971); see also Fletcher, supra note 15, at 229 ("More damage to the intellectual structure of the law of standing can be traced to Data Processing than to any other single decision."); Richard Stewart, Standing for Solidarity, 88 YALE L.J. 1559, 1569 (1979) (book review) (describing Data Processing as an "unredeemed disaster"). 
Kenneth Culp Davis, purporting to interpret the Administrative Procedure Act. ${ }^{109}$ Davis relied on the APA's "adversely affected or aggrieved" language in support of this conclusion. In his view, someone is "adversely affected" if he suffers an injury "in fact."110

For reasons set forth above, this was a misreading of the APA; the language and history of that statute suggested no such renovation of standing law. ${ }^{111}$ The words "adversely affected or aggrieved" are not freestanding, but are followed by "within the meaning of a relevant statute." This juxtaposition shows that Congress was thinking of other laws that created private attorneys general.12 But Davis' misreading received an authoritative endorsement in Data Processing. The Court's opinion was opaque on the connection between injury in fact and Article III. The test seemed to stem from the APA, but the opinion can be read to suggest that Article III is also highly relevant. ${ }^{113}$

\section{Conceptual Confusion, the New Deal, and the Metaphysics of "Injury"}

Data Processing was poorly written, because it left obscure the relationship between standing and Article III, and more fundamentally because it did not explain the legal source of its novel, indeed unprecedented approach to standing. In its basic orientation, however, Data Processing reflected the emerging and highly tenable view, reflected in more plausible interpretations of the APA, that saw regulatory beneficiaries as suffering "legal injuries."114 The case thus bears some resemblance to the lower court opinions on that point, opinions that could claim to rest on the basic APA framework. ${ }^{115}$

a. Beneficiaries as objects, objects as beneficiaries. I have suggested that the emerging principles of standing could be associated with a particular belief about what caused administrative failure. The grant of beneficiary standing stemmed in part from understandings about the diffuse and disorganized character of the class of regulatory beneficiaries. If the beneficiaries had no greater influence than the ob-

109. 3 KenNeth C. Davis, Administrative LAw Treatise $\$ 22.02$, at 211-13 (1958).

110. Id. After Data Processing. Davis argued that injury in fact should be the principal test of standing in Kenneth C. Davis, The Liberalized Law of Standing, 37 U. CHI. L. REV. 450, 47173 (1970).

111. See supra section I.C.

112. Currie, supra note 15 , at 43-44; see also Scalia, supra note 1 , at 887 ; Stewart, supra note 92, at $1725-30$.

113. See the somewhat confusing passage, 397 U.S. at 151-52.

114. See supra note 94 and accompanying text.

115. See supra note 97 and accompanying text; see also Stewart, supra note 92, at 1735. 
jects, and often even less, it seemed odd to say that the objects would be the only ones entitled to seek judicial review.

In a deeper sense, however, we might understand the grant of standing to regulatory beneficiaries as a broad judicial effort to adapt administrative law to the principles and aspirations of the modern state. The New Deal reformation of the American legal system would ultimately make it impossible and indeed hubristic for courts to say that the "objects" of regulation, equipped with common law interests, would receive greater protection than the beneficiaries, equipped with statutory interests. The New Deal had itself been a wholesale attack on the idea that common law interests deserved special constitutional status. ${ }^{116}$ Under the New Deal view, the common law was a regulatory system that should be evaluated pragmatically, in terms of whether it served human liberty and welfare. When it failed to do so, the system had to be supplemented or replaced.

The New Deal, of course, produced a number of new measures designed to protect new interests and to regulate unfair and deceptive trade practices, the securities market, and much more. ${ }^{117}$ The resulting set of legislative and administrative initiatives generally reflected a democratic judgment that the new interests now protected by statute - the interests of consumers, listeners, poor people, and so forth should receive no less protection than the interests traditionally protected by the common law.

By repudiating the distinction between objects and beneficiaries, the new law of standing served to adapt traditional administrative doctrines to the nature and aspirations of modern government. In the context of standing, the reluctance to take this step has been embodied in a private law model of standing - that is, in the idea that standing should be reserved principally to people with common law interests and denied to people without such interests. This idea reflects a Lochner-like conception of public law. ${ }^{118}$ It defines modern public law by reference to common law principles that appear nowhere in the Constitution.

The private law model of standing is based on understandings that are not only without constitutional foundation, but that seemed to be foreclosed by democratic judgments following the New Deal. Indeed, that model seemed to draw upon the discredited view that common law and laissez-faire principles are part of the Constitution, to be

116. See Cass R. Sunstein, The Partial Constitution ch. 2 (forthcoming 1993).

117. See Theodore Lowi, The Personal President 44-66 (1985).

118. On injury in fact as a form of disguised substantive due process, see Fletcher, supra note 15 , at 233. 
deployed by unelected judges as the vehicle for the definition of a system of public law sharply opposed to modern regulatory institutions.

We can go even further. After the New Deal, the very distinction between regulatory beneficiaries and regulatory objects seemed based on a conceptual mistake. That distinction treated the common law as the normal and natural state of affairs; it saw a deviation from the common law as an intrusion on some "object," and as a protection of some "beneficiary." Indeed, the definition of the "object" and the "beneficiary" was parasitic on common law. But this was a way for courts to load the dice. Indeed, this understanding was no longer consistent with the practices and values of modern government.

The so-called regulatory objects were in fact beneficiaries of law, insofar as it was law - statutory or common - that conferred on them the set of entitlements that created a protected sphere of action. Suppose, for example, that an industry attempted to fend off an occupational safety regulation that it believed unlawful. The industry's relevant rights were legal ones, and these established it as a "beneficiary" of positive law. Similarly, the beneficiaries of regulation could equally be seen as "objects" of law insofar as it was the law - statutory or common - that authorized private and public intrusions on their interests. Workers, for example, were the "objects" of the common law insofar as that law enabled employers to exclude them from the employer's land whenever employers so chose. ${ }^{119}$ The rise of the regulatory state rendered the distinction between regulatory objects and regulatory beneficiaries a conceptual anachronism, a relic of the Lochner period.

b. The impossibility of "injury [solely] in fact." There is a related and even deeper conceptual issue, connected with the notion of injury in fact, and bearing both on the current discussion and on the developments culminating in Lujan. The Data Processing Court appears to have thought that it was greatly simplifying matters by shifting from a complex inquiry of law (is there a legal injury?) to an exceedingly simple, law-free inquiry into fact (is there a factual harm?). That Court, and its successors (the Lujan Court among them), seem to assume that whether there is an "injury" can be answered as if it were a purely factual matter - as if the existence of injury depended on some brute fact, not on evaluation, and not on law. But this is false. ${ }^{120}$

In classifying some harms as injuries in fact and other harms as

119. Cf. Jeremy Waldron, Homelessness and the Issue of Freedom, 39 UCLA L. REV. 295, 309-15 (1991) (arguing that property law invades negative rights of the homeless). here.

120. See Fletcher's fine discussion to this effect, supra note 15 , at 231-34, from which I draw 
purely ideological, ${ }^{121}$ courts must inevitably rely on some standard that is normatively laden and independent of facts. If the point seems obscure, it is only because there are reasonably well-established conventions on what counts as an injury, and these conventions tend to disguise the normative judgments and make them seem purely factual. But in every case, the person who brings a lawsuit believes that she has indeed suffered an injury in fact.

When blacks challenge a grant of tax deductions to segregated schools, they believe that the grant is an injury in fact, not that it is purely ideological. ${ }^{122}$ When an environmentalist complains about the destruction of a pristine area, he believes that the loss of that area is indeed an injury to him. When we deny these claims, we are making a judgment based not on any fact, but instead on an inquiry into what should count as a judicially cognizable injury. This judgment may be right, but it has little to do with facts or concreteness.

As stated, my claim may seem obscure, even exotic. It is tempting to respond that there is a real, factual difference between someone who has been fined $\$ 100$ and someone in New York who objects to a policy of racial discrimination in California. One might think that in the former case there "just is" an injury, and that in the latter case there "just isn't." 123 The loss of money is a real and tangible harm; the offense produced by objectionable government policy may be intense, but it is merely offense.

There are indeed factual differences between these cases, but it is not true that the first case involves a factual harm and the second does not. Both cases involve harm, as evidenced by the fact that people in both cases have been prompted to take the time, trouble, and expense to initiate proceedings. We might deny that someone objecting to government policy has suffered harm, and even label him a bystander; ${ }^{124}$ but, if we do this, we are importing our own, value-laden ideas about what things ought to count. We are not simply describing some fact about the world.

If the claim remains obscure, the Havens Realty case ${ }^{125}$ may be helpful. One of the issues in that case was whether standing could be conferred on "testers" - people who do not intend to rent or

121. See Sierra Club v. Morton, 405 U.S. 727 (1972).

122. But cf. Allen v. Wright, 468 U.S. 737, 755-56 (1984) (treating this harm as "abstract").

123. Here, as elsewhere in the law, believing is seeing. As Einstein once said, "It is the theory which decides what we can observe." Werner Heisenberg, Physics and Beyond: ENCOUNTERS AND CONVERSATIONS 63 (1971).

124. See Sierra Club, 405 U.S. at $739-40$.

125. Havens Realty Corp. v. Coleman, 455 U.S. 363 (1982); cf. Fallon, supra note 15, at 4759 (discussing congressional power to grant standing). 
purchase a home or apartment but who pose as renters or purchasers in order to collect information about unlawfully discriminatory racial steering. Without any statute, testers could not possibly have standing. It would not matter if they perceived an "injury in fact" when they were given false, discriminatorily motivated information about the housing market. But Congress declared it unlawful "[t]o represent to any person because of race, color, religion, sex, handicap, familial status, or national origin that any dwelling is not available for inspection, sale, or rental when such dwelling is in fact so available" and created a cause of action to enforce this right. ${ }^{126}$ The Havens Realty Court held that, in view of this statute, Congress had conferred a sort of legal interest on testers and provided that it could be legally redressed. The injury to the "statutorily created right to truthful housing information" was sufficient for constitutional purposes. ${ }^{127}$

It cannot be right to say that the plaintiff in Havens Realty suffered no injury in fact before Congress had acted, and that the civil rights statute somehow conjured up an injury ("in fact"'). Instead the relevant statute created a legally cognizable harm where none had existed before. Despite the Havens Realty Court's bow in the direction of injury in fact, ${ }^{128}$ the case shows that the real question is what harms that people perceive as such ought to be judicially cognizable. The outcome in the case had nothing to do with "injury in fact." It had everything to do with the set of legal rights that Congress had conferred. ${ }^{129}$

In these circumstances, whether there is a so-called nonjusticiable ideological interest, or instead a legally cognizable "actual injury," is a product of legal conventions and nothing else. To people who are part of the legal culture, some harms obviously count as such, but only because those claims are so familiar. Their familiarity often stems from the fact that they were protected at common law. To the same people, some harms are not perceived as such, but only because they

126. 42 U.S.C. $\S \S 3604(d), 3612(a)$ (1988).

127. 455 U.S. at 374.

128. See 455 U.S. at 374.

129. Consider also the closely related case of Trafficante v. Metropolitan Life Ins. Co., 409 U.S. 205 (1972). There, two tenants of a large apartment complex in California complained about their landlord's racially discriminatory practices. They contended that these practices deprived them of "important benefits from interracial association." 409 U.S. at 210. The Court allowed standing under a statute explicitly granting the right to sue. In a concurring opinion, Justice White rightly said that, without the statute, he "would have great difficulty in concluding" that there was a case or controversy. 409 U.S. at 212 . Without the statute, we would say that the plaintiffs had a merely ideological injury; perhaps we would not be able to see the harm they suffered as an injury at all. After the enactment of the statute, however, a unanimous Court concluded that standing could be found. Is it even plausible to think that there was no "injury in fact" before the statute, and thus that the California plaintiffs came to experience an injury ("in fact"l) the day that Congress passed a law in the District of Columbia? 
are unfamiliar. Their unfamiliarity often stems from the fact that they are foreign to the common law.

Whether an injury is cognizable, however, should not depend on its familiarity or its common law pedigree; this approach would represent a conspicuous reintroduction of Lochner-era notions of substantive due process. Whether an injury is cognizable should depend on what the legislature has said, explicitly or implicitly, or on the definitions of injury provided in the various relevant sources of positive law. The Court should abandon the metaphysics of injury in fact. It should return to the question whether a cause of action has been conferred on the plaintiff.

c. On law and fact. If my point still remains unclear, we might think a bit about what it really means for someone to have a legal interest in a problem or dispute. If I am offended because Jones commits a tort against Smith, I apparently have no such interest, and I have no standing to sue Jones. But if Smith is my spouse, or my employee, the law may well have given me a legal interest, and I may well have standing to sue. If the actions of the U.S. government result in destruction of the rainforest, I have no legal interest and no standing to sue the government, and there is no case or controversy under Article III. But suppose that Congress grants American citizens standing to sue their government for acts destructive of the rainforest. If it does so, it has, in effect, granted every American both a beneficial interest in the rainforest and a legal right to protect that interest in court. A cause of action, of course, is a property interest. ${ }^{130}$

When Congress creates a cause of action enabling people to complain against racial discrimination, consumer fraud, or destruction of environmental assets, it is really giving people a kind of property right in a certain state of affairs. ${ }^{131}$ Invasion of that property right is the relevant injury. If some of these things seem to be "property" only ambiguously, we might recall a lesson from law school's first year: property is simply a bundle of sticks, and property rights can exist in a wide variety of tangible and intangible matters. Nothing in the Constitution forbids Congress from creating property interests of these various kinds or from allowing people to vindicate those interests in court. ${ }^{132}$

130. See Mullane v. Central Hanover Bank \& Trust Co., 339 U.S. 306, 313 (1950) (noting that denial of right to bring suit can constitute a deprivation of property).

131. I am grateful to Michael McConnell for help with the points in this paragraph, though he bears no responsibility for the use to which I have put them here.

132. Compare Joseph Vining's eloquent meditation on standing, written in the heyday of the apparent rejection of the legal interest test. See JosEPH VINING, LEGAL IDENTITY (1978). Vining contends that American law had witnessed an abandonment of property-based thinking to- 
The resistance to this general approach stems from the deep familiarity of the common law catalogue of legal rights; people, or more importantly judges pondering "injury in fact," tend to think of property in terms of that particular catalogue. But the notion that the common law exhausts Congress' power, and that the Constitution forbids it from intruding on that catalogue or creating new legal rights, is (I repeat) simply a modern form of substantive due process. Indeed, the parallel with substantive due process is very precise. In the early twentieth century, the common law catalogue was similarly thought to be part of the state of nature, or of "how things are," and thus to operate as a barrier to legislative efforts to redefine property interests. ${ }^{133}$ The examples suggest that there are innumerable "injuries in fact" produced by public and private action. Many of those injuries might well produce lawsuits. But an injury can become judicially cognizable if and only if it has received legal status from some source of law. To this extent, the Data Processing Court's attempted shift from law to fact was doomed to fail from the beginning.

I conclude with an analogy. For many decades, a conflict of laws between two jurisdictions would be resolved by seeing where the right had "vested."134 If the right had vested in state $A$, that state's law would apply; if it had vested in state $B$, the parties would be governed by the law of state $B$. Courts approached the question where has the right vested? as if it were a simple issue of fact. But eventually it became clear that this was no factual inquiry, but instead a policy judg. ment, to be answered by reference to the law of the relevant states and, where these did not speak, to the best possible judicial inferences on the matter. ${ }^{135}$

The same should be true of the law of standing. In the long run, the injury-in-fact test will, I believe, be seen as the contemporary analogue of the discredited notion of "vested rights" in the law of conflicts.

\section{The Congressionally Created Citizen Suit}

So much for conceptual matters. A final development is relevant to the period under discussion. Spurred by judicial developments and

ward a new emphasis on the definition and implementation of public values. See id. at 23-27. If what I am suggesting is right, however, abandoning the touchstone of property is not so easy. Standing depends on some legal interest, however much we might try to redirect the inquiry, and if it depends on legal interest, it depends on something like property.

133. See supra note 80 and accompanying text.

134. See Alabama Great So. R.R. Co. v. Carroll, 11 So. 803 (Ala. 1892) (applying the "place of the wrong" rule).

135. See Larry Kramer, Rethinking Choice of Law, 90 CoLUM. L. REv. 277 (1990). 
suspicion of agency "capture," Congress created a wide range of citizens' suits. ${ }^{136}$ These suits would be available against (a) private defendants operating in violation of statute and (b) administrators failing to enforce the law as Congress required. Congress was especially enthusiastic about such suits in the environmental area, addressing the fear that statutory commitments would be threatened by bureaucratic failure. With a number of devices, including the citizen suit, Congress hoped to overcome administrative laxity and unenthusiasm, and also to counteract the relatively weak political influence of beneficiaries. ${ }^{137}$ Congress did not, however, devote much attention to the constitutionality of citizen standing, and the issue was to remain open for many years.

\section{E. Redressability, Causation, and the Separation of Powers}

The fifth stage of standing law is the contemporary one. I begin with description and then turn to some apparent motivating assumptions.

\section{New Departures}

This period is defined principally by a series of cases establishing that the plaintiff does not suffer injury in fact unless he can show that (a) the injury is attributable to the conduct of the defendant and (b) the injury is likely to be redressed by a decree on his behalf. A less obvious but equally important development is the Court's tacit insistence that the requisite injury in fact be defined in common law-like terms. A still less obvious development is the renewed use of Article II in standing cases; indeed, it may not be unfair to say that Article II concerns are coming to dominate the interpretation of Article III. As I will suggest, the Lujan opinion is motivated by many of the concerns expressed in Justice Scalia's dissenting opinion in Morrison v. Olson, ${ }^{138}$ the independent counsel case.

136. See supra note 11 .

137. In my view, this is an inadequate diagnosis of the basic problem of bureaucratic failure. A large part of that problem is command and control regulation and inadequate congressional attention to the problem of incentives imposed on administrative agencies and industries alike. The question is therefore not whether we should have "more" as opposed to "less" enforcement, but instead how to create incentives for the right level of enforcement. Command and control regulation accompanied by the citizen suit is hardly an ideal solution. See R. Shep Melnick, Pollution Deadlines and the Coalition for Failure, in ENVIRONMENTAL Politics 89 (Michael S. Greve \& Fred L. Smith, Jr., eds., 1992); infra text accompanying note 265-69. For a more general diagnosis, see Cass R. Sunstein, Democratizing America Through Law, 25 SufFolk U. L. REv. 949 (1991); Cass R. Sunstein, Paradoxes of the Regulatory State, 57 U. CHI. L. REV. 407 (1990).

138. 487 U.S. 654 (1988). 
Notably, most of the key cases have involved attempts by some plaintiff to require the executive branch to fulfill its statutory responsibilities by enforcing the law more vigorously. The initial step was Linda R.S. v. Richard D., ${ }^{139}$ in which a mother of an illegitimate child brought suit against the local prosecutor, contending that his failure to initiate child support proceedings against the child's father caused her harm. The Court denied standing on the ground that it was unclear whether a decree in the plaintiff's favor would remedy that harm. The father might simply go to jail, leaving the mother no better off than before. According to the Court, this possibility rendered purely "speculative" whether prosecutorial proceedings would yield the desired outcome. ${ }^{140}$

The Linda R.S. decision was followed by Simon v. Eastern Kentucky Welfare Rights Organization. ${ }^{141}$ There, the Court denied standing to indigent people protesting a change in tax policy which reduced the obligation of hospitals to provide medical services to the indigent. The plaintiffs claimed that they had sought and been denied medical treatment as a result of this ruling. According to the Court, the plaintiffs could not show that the changed policy actually affected their own situation. "It is purely speculative whether the denials of service ... fairly can be traced to petitioners' 'encouragement' or instead result from decisions made by the hospitals without regard to the tax implications." 142

The third key case was Allen $v$. Wright. ${ }^{143}$ In that case, the Court said that parents of black children attending public schools that were undergoing desegregation lacked standing to challenge the grant of tax deductions to segregated private schools. The pivotal point was that the plaintiffs could not show that a decree in their favor would actually affect their children. Denial of the tax deduction would not necessarily benefit the plaintiffs. Any causal relationship between the deduction and the progress of any particular desegregation plan was, again, fatally "speculative."144

An especially important section of the Allen opinion referred to Article II and to the separation of powers. The Court explained that, if the plaintiffs were to have standing, judges would become "virtually

139. 410 U.S. 614 (1973).

140. 410 U.S. at 618.

141. 426 U.S. 26 (1976).

142. 426 U.S. at $42-43$.

143. 468 U.S. 737 (1984); see also Duke Power Co. v. Carolina Envtl. Study Group, Inc., 438 U.S. 59 (1978); Warth v. Seldin, 422 U.S. 490 (1975).

144. 468 U.S. at 758. 
continuing monitors of the wisdom and soundness of Executive action." 145 The Court also suggested that standing here would risk judicial usurpation of the President's power to "take Care that the Laws be faithfully executed."146 Standing should thus be unavailable "in a case brought, not to enforce specific legal obligations whose violation works a direct harm, but to seek a restructuring of the apparatus established by the Executive Branch to fulfill its legal duties."147 These suggestions - with Article II concerns prominently appearing in an Article III setting - have proved extremely important.

\section{General Trends in Administrative Law}

The cases in this fifth period of standing law reveal a more general trend in administrative law, a trend of which Lujan is very much a part. The fourth stage had witnessed a fundamental assault on the distinction between regulated objects and regulatory beneficiaries. In the past fifteen years, however, the Supreme Court has unmistakably if usually implicitly insisted on that very distinction.

Professor Antonin Scalia of the University of Chicago Law School made his enthusiasm for the object-beneficiary distinction clear in an influential 1978 article on the Vermont Yankee case. ${ }^{148}$ In one of the first statements of this position, Scalia wrote that aggressive judicial review of administrative action would be most understandable when regulated industries were at risk and least understandable when regulatory beneficiaries sought greater regulation. ${ }^{149}$ The Vermont Yankee case itself had nothing to do with standing. But there the Court expressed firm disapproval of active judicial policing of administrative policies, and perhaps it was not a coincidence that the case involved a suit by regulatory beneficiaries who wanted to bring about more stringent regulatory controls on nuclear power. ${ }^{150}$

A key -case, highly representative of current tendencies, is Heckler v. Chaney. ${ }^{151}$ There the Court held that agency inaction, unlike agency action, would be presumed immune from judicial review. In so

145. 468 U.S. at 760 (quoting Laird v. Tatum, 408 U.S. 1, 15 (1972)).

146. 468 U.S. at 761 (quoting U.S. CoNST. art. II, § 3).

147. 468 U.S. at 761.

148. Antonin Scalia, Vermont Yankee: The APA, the D.C. Circuit, and the Supreme Court, 1978 SUP. Cr. REV. 345; see Vermont Yankee Nuclear Power Corp. v. Natural Resources Council, Inc., 435 U.S. 518 (1978).

149. See Scalia, supra note 148 , at $388-89$.

150. For a powerful defense of Vermont Yankee's treatment of the substantive issue, see Stephen Breyer, Vermont Yankee and the Court's Role in the Nuclear Energy Controversy, 91 HARV. L. REV. 1833 (1978).

151. 470 U.S. 821 (1985). 
holding, the Court apparently drew a distinction between regulated objects and regulatory beneficiaries. Indeed, the Court defended its conclusion in part by suggesting that, when an agency fails to act, it "does not exercise its coercive power ... and thus does not infringe upon areas that courts are often called upon to protect."152 Apparently, only the interests of the objects generally are protected. The Chaney Court also referred to the Take Care Clause of Article II, suggesting that this provided a further reason for judicial reluctance to supervise administrative inaction. In this way, Heckler $v$. Chaney is of a piece with Allen v. Wright and Lujan. In many other cases, the Court has rejected challenges to administrative decisions by regulatory beneficiaries. ${ }^{153}$

As noted, most of the key standing cases involved efforts by regulatory beneficiaries to require enforcement of regulatory statutes. Before Lujan, the law thus stood poised for an explicit judicial distinction between suits by objects and suits by beneficiaries.

\section{3. "Beneficiaries" Versus "Objects"}

What underlies the current trend? There are several possibilities, and all of them have probably contributed to a growing enthusiasm for the apparently discredited distinction between regulatory beneficiaries and regulated objects. The possibilities should be seen as a modern theoretical rejoinder to the 1960 s and 1970 s fear of agency capture by regulated objects.

Some observers, for example, think that government regulation of private ordering is constitutionally suspect. ${ }^{154}$ The academic enthusiasm for greater constitutional checks on the regulatory state has apparently found modest judicial support. ${ }^{155}$ Whether or not government regulation is unconstitutional, many people think that it is morally problematic, and perhaps this view too has support on the Supreme Court. ${ }^{156}$ Other people think that government regulation does not work in practice - that it produces high social costs for du-

152. 470 U.S. at 832.

153. See, e.g., Robertson v. Methow Valley Citizen Council, 490 U.S. 332 (1989); Baltimore Gas \& Elec. Co. v. Natural Resources Defense Council, Inc., 462 U.S. 87 (1983).

154. See Richard Epstein, Takings (1985).

155. See Lucas v. South Carolina Coastal Council, 112 S. Ct. 2886 (1992) (finding that environmental regulation was a taking).

156. Something of this kind may be implicit in Industrial Union Dept. v. American Petroleum Inst., 448 U.S. 607, 645 (1980) (plurality opinion of Stevens, J.) (agency's argument for stricter regulatory standards would "justify pervasive regulation limited only by the constraint of feasibility ... [and] would give [the agency] power to impose enormous costs that might produce little, if any, discernible benefit"). 
bious benefits. ${ }^{157}$ This view has influenced the executive branch, and it has appeared to play a role in the courts as well. ${ }^{158}$ Many people think that administrators are systematically inclined toward overenforcement of regulatory statutes, or toward "capture" by regulatory beneficiaries. ${ }^{159}$ Quite apart from issues of substance, some urge that judicial compulsion of regulatory action is unconstitutional on Article II grounds or at least constitutionally troublesome. ${ }^{160}$ Others think that courts cannot possibly play a fruitful role in assuring adequate implementation of regulatory statutes. ${ }^{161}$ Some or all of these ideas undoubtedly help explain what has become an unmistakable trend in favor of greater judicial insistence on the distinction between suits by regulating beneficiaries and suits by regulated objects. ${ }^{162}$

\section{LUJAN: DESCRIPTION AND APPRAISAL}

In this Part, I turn to Lujan. ${ }^{163}$ I first discuss what the Court said and then evaluate its reasoning. Two detours will be necessary: first, to address Justice Scalia's conception of standing; and second, to deal with the role of the citizen suit in environmental and regulatory policy. I conclude with a brief suggestion about how Lujan should have been written.

\section{A. What the Court Said}

The Lujan case arose under the Endangered Species Act of 1973 (ESA). ${ }^{164}$ The ESA is an aggressive set of protections for endangered species. ${ }^{165}$ Its key provision says that "Each Federal agency shall, in consultation with and with the assistance of the Secretary [of the Interior], insure that any action authorized, funded, or carried out by such agency ... is not likely to jeopardize the continued existence of any endangered species...."166

157. See, e.g., Chicago Studies in Polmtical Economy (George J. Stigler ed., 1988).

158. See Corrosion Proof Fittings v. EPA, 947 F.2d 1201 (5th Cir. 1991); Exec. Order No. 12,291, 46 Fed. Reg. 13,193 (1981); Exec. Order No. 12,498, 50 Fed. Reg. 10,316 (1985).

159. See, e.g., NiSKANEN, supra note 101, at 210-11.

160. See JEREMY RABKin, Judicial Compulsions (1989).

161. See R. Shep Melnick, Regulation and the Courts: The Case of the Clean AIR ACT (1983).

162. I will not respond to all of these claims here; I believe that, at best, they capture some partial truths. See Cass R. SUNSTEIn, AfTER the Rights Revolution: ReCONCEIVING the Regulatory STATE (1990).

163. Lujan v. Defenders of Wildlife, 112 S. Ct. 2130 (1992).

164. Pub. L. No. 93-205, 81 Stat. 884 (codified as amended at 16 U.S.C. $\S \S 1531-44$ (1988)).

165. TVA v. Hill, 437 U.S. 153 (1978), is the celebrated illustration confirming this point.

166. 16 U.S.C. $\S 1536(a)(2)$ (1988). 
For many years it has been uncertain whether the obligations of the ESA apply to actions of the U.S. government that are taken in foreign countries. In 1978, the relevant authorities agreed that the ESA did indeed apply outside the United States. ${ }^{167}$ But in 1983, the Interior Department initiated a change in its position. An important new regulation, ultimately issued in 1986, announced that the ESA would apply only to actions within the United States or on the high seas. 168

The regulation had a number of important consequences. American agencies funding foreign projects were no longer required to consult with the Secretary of the Interior if their projects would jeopardize the existence of endangered species. The ESA would provide no obstacle to the expenditure of American taxpayer dollars to projects that would threaten to eliminate endangered species outside U.S. borders.

Environmental organizations, including Defenders of Wildlife, brought suit, claiming that the new regulation violated the statute. To establish standing, two members of Defenders of Wildlife claimed that they suffered an injury in fact. Joyce Kelly swore in an affidavit that she had traveled to Egypt in 1986 and viewed the habitat of the endangered Nile crocodile. She claimed that she "intended to do so again, and hoped to observe the crocodile directly." Amy Skilbred claimed that she had traveled to Sri Lanka in 1981 and observed the habitat of "endangered species such as the Asian elephant and the leopard." She also claimed that she intended to return to Sri Lanka to see members of these species. In a deposition, she acknowledged that she did not have a certain date for return. ${ }^{169}$

The Court's opinion, devoted entirely to the issue of standing, is quite straightforward. It falls into four parts: a general statement about standing; a discussion of injury in fact; an assessment of redressability; and a treatment of the citizen suit.

The general statement begins with a description of the function of standing in a system of separation of powers. According to the Court, Article III requires an "irreducible constitutional minimum of standing," with three elements: (1) an injury in fact that is both (a) concrete and particularized and (b) actual or imminent rather than conjectural or hypothetical; (2) a demonstration that the injury is fairly traceable to the acts of the defendant, rather than of some third party; and (3) a

167. See 43 Fed. Reg. 874 (1978).

168. 48 Fed. Reg. 29,990 (1983) (proposing this result); 50 C.F.R. $\S 402.01$ (1991) (codifying final regulation).

169. Lujan, 112 S. Ct. at 2138. 
showing that it is likely that the injury will be redressed by a decision favorable to the plaintiff. ${ }^{170}$

This opening statement breaks little new ground. But the Court added that the standing issue will often be affected by "whether the plaintiff is himself an object of the action (or forgone action) at issue."171 If the plaintiff is an object, the three requirements will ordinarily be met. But when an "injury arises from the government's allegedly unlawful regulation (or lack of regulation) of someone else, much more is needed."172 In such cases, there is the problem that "causation and redressability ordinarily hinge on the response of the regulated (or regulable) third party to the government action or inaction - and perhaps on the response of others as well."173 The Court suggested that in such cases standing "is ordinarily 'substantially more difficult' to establish."174 The Court had implicitly drawn this distinction in Allen v. Wright, ${ }^{175}$ but Lujan was the first case explicitly to mark out the categories.

So much for the preliminaries. The Court's first specific holding was that an injury in fact had not been established. The intention to visit the places harboring endangered species was not enough. The plaintiffs had set out no particular plans. They specified no time when their indefinite plans would materialize. Thus they had shown no "actual or imminent" injury. ${ }^{176}$ Nor could plaintiffs show injuries in fact by demonstrating a nexus linking the affected habitats with all the world's ecosystems, or linking their own "professional" interests in observing endangered species with the interests of all persons so engaged. ${ }^{177}$ The fact that ecosystems are generally interrelated was not enough, because the plaintiffs could not show that they used portions of an ecosystem "perceptibly affected by the unlawful action in question."178 Standing was similarly not available to anyone having an interest in studying or seeing endangered species, because of a professional commitment or otherwise. There must be "a factual showing of perceptible harm."179 This, then, was the Court's reason-

170. 112 S. Ct. at 2136 .

171. 112 S. Ct. at 2137.

172. 112 S. Ct. at 2137.

173. 112 S. Ct. at 2137.

174. $112 \mathrm{~S}$. Ct. at 2137.

175. 468 U.S. 737 (1984); see supra notes $143-47$ and accompanying text.

176. 112 S. Ct. at 2138.

177. 112 S. Ct. at 2139.

178. 112 S: Ct. at 2139.

179. 112 S. Ct. at 2139 . The plurality did not foreclose the "nexus" approach to injury in fact. Justice Kennedy's concurrence preserved the possibility that similar "nexus" theories 
ing on injury in fact.

The second conclusion in Justice Scalia's opinion, accepted by only a plurality of the Court, was that the plaintiffs could not show redressability. According to the plurality, the difficulty lay in the fact that the plaintiffs were challenging a general regulation not requiring consultation with the Secretary of the Interior for funding actions outside of the United States. There were two problems, suggesting that the plaintiffs might not benefit from a decree in their favor.

First, suppose that the district court awarded relief against the Secretary; suppose that it required the Secretary to issue a regulation mandating consultation with him for foreign projects threatening an endangered species. It would remain unclear that the funding agencies would be bound by this regulation. They might simply ignore it; they might not consult at all. For this reason, there would be no clear benefits to the plaintiffs from a favorable ruling.

Second, the American agencies provide only part of the funding for the relevant foreign projects. Most of the money comes from elsewhere. "AID, for example, has provided less than $10 \%$ of the funding" for one of the projects at issue in the case. ${ }^{180}$ Justice Scalia found it unclear whether the elimination of that partial fraction would affect the projects or the species in question. "[I]t is entirely conjectural whether the nonagency activity that affects respondents will be altered or affected by the agency action they seek to achieve."181 The plaintiffs could not show redressability, because a decree on their behalf might not yield their desired result.

The Court's third conclusion was its most important. The court of appeals had relied on the citizen-suit provision of the ESA, permitting "any person [to] commence a civil suit on his own behalf $(\mathrm{A})$ to enjoin any person, including the United States and any other governmental instrumentality or agency ... who is alleged to be in violation of any provision of this chapter." 182 In a discussion with large consequences, the Court held in effect that this provision was unconstitutional as applied.

The Court emphasized that Article III requires something more than "a generally available grievance about government - claiming only harm to his and every citizen's interest in proper application of the Constitution and laws, and seeking relief that no more directly and

might serve to establish injuries in fact in other cases. See $112 \mathrm{~S}$. Ct. at 2146 (Kennedy, J., concurring); infra text accompanying note 189.

180. 112 S. Ct. at 2142 .

181. 112 S. Ct. at 2142.

182. 16 U.S.C. $\S 1540(\mathrm{~g})(1)(1988)$. 
tangibly benefits him than it does the public at large."183 To support this contention, the Court cited cases from the 1920s and 1930s rejecting suits by citizens complaining about government action on constitutional grounds. It also pointed to a number of post-1970 cases appearing to suggest that Article III in fact required a particularized injury. ${ }^{184}$

The Court acknowledged that in none of these cases had Congress explicitly granted citizens a right to bring suit. But in the Court's view, this difference did not matter. The Court emphasized that "[v]indicating the public interest (including the public interest in government observance of the Constitution and laws) is the function of Congress and the Chief Executive."185 In particular, the Court said that if Congress could turn "the undifferentiated public interest in executive officers' compliance with the law into an 'individual right' vindicable in the courts," 186 it would be transferring "from the President to the courts the Chief Executive's most important constitutional duty," that is, "to 'take Care that the Laws be faithfully executed." "187 Thus, the Court's decision rested on the fear that, if Congress could grant standing here, it would turn the judges into overseers, and usurpers, of the President himself. Here Article II helped give context to Article III.

Justice Kennedy, joined by Justice Souter, offered an intriguing and somewhat ambiguous concurring opinion. He emphasized that, had the plaintiffs purchased an airplane ticket, set a specific date to visit the habitat of the endangered species mentioned, or used the relevant sites on a regular basis, they might have established standing in a case of this kind. ${ }^{188}$ Indeed, Justice Kennedy was not willing to foreclose the possibility that standing might be allowed on the basis of some "nexus" theory. ${ }^{189} \mathrm{He}$ indicated that courts "must be sensitive to the articulation of new rights of action that do not have clear analogs in our common-law tradition." 190 Thus "Congress has the power to define injuries and articulate chains of causation that will give rise to a case or controversy where none existed before." 191 But in this

183. $112 \mathrm{~S}$. Ct. at 2143.

184. 112 S. Ct. at 2144.

185. 112 S. Ct. at 2145.

186. 112 S. Ct. at 2145.

187. 112 S. Ct. at 2145 (quoting U.S. CoNST. art II, § 3).

188. $112 \mathrm{~S}$. Ct. at 2146 (Kennedy, J., concurring).

189. 112 S. Ct. at 2146 (Kennedy, J., concurring).

190. 112 S. Ct. at 2146 (Kennedy, J., concurring).

191. 112 S. Ct. at 2146-47 (Kennedy, J., concurring). 
case Congress refused to "identify the injury it seeks to vindicate and relate the injury to the class of persons entitled to bring suit."192 In any case, Article III does not permit Congress to allow courts "to vindicate the public's nonconcrete interest in the proper administration of the laws. While it does not matter how many persons have been injured by the challenged action, the party bringing suit must show that the action injures him in a concrete and personal way."193

\section{B. Evaluation}

Each conclusion in the principal opinion is of considerable interest. I take them up in sequence.

\section{Injury}

The Court's conclusion on the matter of injury raises three different issues. The first is whether the plaintiffs did indeed show an injury, assuming the Court's definition of what the injury was. The second is whether the plaintiffs could have been permitted to recharacterize their injury in a different way. The third has to do with the general problems in the very notion of injury in fact.

If we accept the Court's definition of injury, its conclusion was perhaps an innovation, but not an entirely implausible one. Its chief importance lay in the insistence that the injury must be "imminent." It is true that none of the plaintiffs could prove that they would revisit the relevant sites. So long as injury in fact is required, perhaps this point is decisive. Perhaps the plaintiffs failed to show with sufficient

192. 112 S. Ct. at 2147 (Kennedy, J., concurring).

193. 112 S. Ct. at 2147 (Kennedy, J., concurring).

There were two other separate opinions. Justice Stevens concurred in the judgment. $112 \mathrm{~S}$. $\mathrm{Ct}$. at 2147. He concluded that plaintiffs had standing because some of them had visited a critical habitat of an endangered species, shown a professional interest in preserving the species and its habitats, and intended to revisit them in the future. They did not need to show that the return visit was imminent. They would suffer the relevant injury, sufficient for Article III purposes, as soon as the species was destroyed. Justice Stevens also contested the matter of redressability. He would have presumed that, if the Court required funding agencies to consult with the Secretary, the agencies would abide by the Court's interpretation, and that consultation would yield tangible results. Justice Stevens concurred only because he concluded that, on the merits, the ESA did not apply overseas.

Justice Blackmun dissented in an opinion joined by Justice O'Connor. 112 S. Ct. at 2151. Justice Blackmun emphasized that Kelly and Skilbred swore that they would soon return to relevant project sites. In his view, a reasonable finder of fact could find that this was likely, thus confirming plaintiffs' injury in fact. The distant location of the Asian elephant was irrelevant to the fact that its destruction would impose a professional injury on the plaintiffs. Moreover, plaintiffs met the redressability requirement, for a threatened withdrawal of American funding might well affect foreign government conduct. If American funds were withdrawn, the possibility that the project might be scaled back or eliminated was sufficient to establish redressability. 112 S. Ct. at 2156-57. 
certainty that they would be affected by the government decisions at issue in the case.

An argument to the contrary would suggest that one of the original purposes of the injury-in-fact test, made explicit in Data Processing, ${ }^{194}$ was to ensure that standing could be a simple, threshold determination, without an elaborate process of assessing the pleadings. In any case, it would be strange and unfortunate if jurisdictional issues turned out to rest on complex factual inquiries. In this light, it might seem to make little sense to require plaintiffs to purchase an airline ticket. Perhaps this is unnecessary formalism. But the Court's point is at least one on which reasonable people can differ. If we put the congressional creation of citizen suits to one side, and if the outcome in Lujan turns on the fact that plaintiffs made an inadequate showing that they would indeed return to the relevant sites, the Court's decision is hardly implausible.

A trickier issue, not dealt with in any of the opinions, involves the appropriate characterization of the injury. To understand the point, we need to look at a famous case that is seemingly far afield. Regents of the University of California v. Bakke ${ }^{195}$ presented an often-overlooked problem of standing. Bakke himself could not show that without the affirmative action program he challenged, he would have been admitted to the medical school of the University of California at Davis. It was therefore argued that he could not meet the Article III requirement of injury in fact.

The Court responded in a way that has potentially major implications:

[E]ven if Bakke had been unable to prove that he would have been admitted in the absence of the special program, it would not follow that he lacked standing. . . . The trial court found such an injury, apart from failure to be admitted, in the University's decision not to permit Bakke to compete for all 100 places in the class, simply because of his race. ${ }^{196}$

What happened here was that the Bakke Court found injury, causation, and redressability by the simple doctrinal device of recharacterizing the injury. In Bakke, the Court described the injury as involving not admission to medical school but the opportunity to compete on equal terms. The Court has not explicitly used this technique in any other case, ${ }^{197}$ but it might easily have done so. In Simon v. Eastern Kentucky Welfare Rights Organization [EKWRO], for example, the

194. See Association of Data Processing Serv. Orgs. v. Camp, 397 U.S. 150, 152-54 (1970).

195. 438 U.S. 265 (1978).

196. 438 U.S. at $280-81$ n.14.

197. But see the housing discrimination cases discussed supra text accompanying notes $125-$ 29. The idea that there was redressability there, in the ordinary sense, is odd. See Logan, supra 
Court might have said that the injury consisted not of a refusal of admission to a hospital, but instead of a decision not to permit the plaintiffs to have an opportunity to be admitted on the terms specified by law, simply because of unlawful incentives created by the IRS. 198 In this way, Bakke and $E K W R O$ were structurally similar. Likewise, in Allen v. Wright, ${ }^{199}$ the Court might have recharacterized the injury as an opportunity not to have the desegregation process distorted by the incentives created through the grant of unlawful tax deductions to private schools.

Suppose that, in Lujan itself, the plaintiffs had claimed that their injury consisted not of an inability to see certain species but of a diminished opportunity to do so. This diminished opportunity allegedly resulted from unlawful government action. On this view, the ESA was designed to ensure not that no species would become extinct - that was not an adequate description of the injury at issue - but more precisely that endangered species would not be subject to increased threats of extinction because of federal governmental action. The injury of which the plaintiffs complained was the harm to their professional and tourist opportunities created by those increased risks.

On this view, the injury in Lujan would therefore run parallel to that created by violations of the Equal Protection Clause, which is designed not to ensure that certain people get into medical school, but instead that they are not subject to increased risks of exclusion because of racial factors. Structurally, a plausible conception of the harm in Lujan would accord with that in Bakke - a harm to an opportunity, here the opportunity to observe certain species.

If Bakke is right on the standing question, it is not so easy to explain why the same approach would have been wrong in Lujan. If there is a difference between the relevant injuries, it may stem from the fact that the Equal Protection Clause conspicuously protects the right to compete on an equal basis; this is not a contestable interpretation (however much we may dispute what "equal" means). The clause does not confer the right to a certain set of favorable outcomes. The ESA is far more ambiguous on this score. Perhaps the injury against which it guards is the actual loss of an endangered species because of U.S. government action, rather than the diminished opportunity to view such a species in its natural habitat.

But this interpretation is far from clear. Why could we not view

note 15 , at $77-81$. The Court did not require ordinary redressability because there was a clear invasion of a statutory right and a clear congressional grant of standing. See id.

198. 426 U.S. 26 (1976); see supra notes 141-42 and accompanying text (discussing case).

199. 468 U.S. 737 (1984). 
the ESA as protecting the right to have the opportunity to see endangered species unaffected by adverse action by government agencies? Surely Congress has the constitutional power to create such a right. But courts may wish to avoid this interpretation in the absence of an especially clear congressional statement. The recharacterization of injuries to include less particularized, "opportunity" harms does expand the category of people entitled to bring suit. At some point the recharacterization will mean that all, or almost all, citizens are harmed in the same way. Prudential considerations might well counsel against this step. ${ }^{200}$

This point suggests that, when Congress has not spoken clearly, courts should not allow injuries to be characterized in such broad terms that the plaintiff is not particularly affected. But in Lujan, there was no such problem. The plaintiffs had a fully plausible professional and educational interest in the species at issue. If the plaintiffs had tried to characterize their injury as the diminished opportunity to promote their interests, they should have been permitted to do so. There is little law on this issue, but perhaps inventive plaintiffs will be permitted to make efforts in this direction in the future.

I conclude that, as the case was litigated, the Court's conclusion on injury in fact was probably incorrect, but plausible, and in any case no great innovation. Because of the way the case was litigated, there was no occasion to think hard about the appropriate characterization of the injury. Thus the implications of Bakke remain unclear.

The third problem involves the notion of injury in fact. I have suggested that whether there is such an injury turns not merely on facts but also on whether the law has recognized certain harms as legal ones. ${ }^{201}$ This principle means, for example, that a person in New York has no standing to challenge racial discrimination in Iowa, as no law treats distant discrimination as an injury. The same result would occur with a Lujan-style action brought before enactment of the ESA. But now suppose that Congress has given to all Americans a kind of beneficial legal interest in the survival of the Nile crocodile, at least in the sense that it has granted each of us a jointly held property right, operating against acts of the U.S. government that threaten to destroy the species. Suppose too that Congress has granted every American the right to sue to vindicate that property right. What in the Constitution forbids this action? Surely not the Due Process Clause; surely not Article II; and surely not Article III.

200. Cf. Fletcher, supra note 15, at 278-79 (arguing that broadened congressional grants of standing may undercut rights of those most directly affected).

201. See supra notes 120-29 and accompanying text. 
I suggest that this is very much what happened in the ESA itself. By creating citizen standing, Congress in essence created the relevant property interest and allowed citizens to vindicate it. To this extent, Congress did indeed create the requisite injury in fact, and the Court should have recognized it as such. If a problem remains, perhaps it lies in Congress' failure to be explicit on the point. This may ultimately be the meaning of Justice Kennedy's concurring opinion, and if so it remains possible for Congress to solve the problem through more careful drafting. I discuss these points in Part III. ${ }^{202}$

\section{Redressability}

On the question of redressability, there was no majority for the Court. Three justices saw no problem with redressability; two Justices refused to speak to the issue; four Justices found a constitutional defect. Because no majority spoke, the Lujan case has little precedential value on this question.

To evaluate the issue of redressability in the recent cases, it is important to understand why courts require redressability at all. The basic reason is akin to that underlying the prohibition on advisory opinions. Let us suppose that an injury in fact is required. If a decree in the plaintiff's favor will not remedy that injury, is not such a decree an advisory opinion, at least with respect to the plaintiff? If the harm to the plaintiff will persist after the decree, why should the court become involved at all? For this reason, the redressability requirement seems to be a reasonable inference from the requirement of injury in fact. In the abstract, it makes perfect sense.

The difficulty arises in cases in which Congress has attempted to restructure administrative and private incentives so as to bring about structural or systemic change, but in a way that will not necessarily yield the particular outcomes sought in particular cases. Assume, for example, that Congress expressly forbids the grant of federal funds to international projects that threaten endangered species. If the agency withholds the funds, no particular project will necessarily be stopped, nor will any particular species necessarily be saved. The project may go forward without American participation, or the species may not survive even without the project. Or suppose that Congress forbids universities receiving federal funds from discriminating on the basis of race. If the funds are withheld, discrimination may continue. No prediction on this score can avoid being "speculative."

In cases of this kind, the relevant harm consists of a grant of funds 
that makes certain harms more likely as a result of the contribution of American tax dollars - the loss of a species or the incidence of discrimination. The examples illustrate what Congress frequently attempts to do in the areas of funding requirements, environmental protection, and risk regulation in general: it attempts to change incentives in a way that should produce aggregate changes without necessarily affecting outcomes in particular cases. The reduction of sulfur dioxide emission levels in California will reduce the risk that people will suffer from respiratory disease. But it will usually be speculative in any particular case whether the mandated reduction will make any difference to a particular human life.

In such cases, whether an injury is redressable depends on how it is characterized. If the injury is described in sharply particularistic, common law-like terms, it will not be redressable, since the consequences of victory for any particular plaintiff cannot be ascertained in advance. But if it is characterized as an increased risk of harm - if that is the relevant injury - it will certainly be redressed by a decree in the plaintiff's favor. A decision to require compliance with national ambient air quality standards will make the air cleaner, and that will decrease the risk of harm to people in the relevant territory. Cases of this sort are a staple of modern administrative law. Much the same analysis might be applied to a decision to withdraw funds from schools that discriminate on the basis of race or sex.

The point casts light on Justice Kennedy's suggestion that courts "must be sensitive to the articulation of new rights of action that do not have clear analogs in our common-law tradition."203 Indeed, in these sorts of cases it makes little sense to ask if a decree in the plaintiff's favor will remedy a common law-like injury. The question is: What is the harm that Congress sought to prevent? To answer this question, a court has to engage in statutory interpretation. In the end, the issue of redressability, like that of injury in fact, turns on what Congress has provided. Redressability might even be understood as a crude proxy for an inquiry into legislative instructions about who is entitled to bring suit.

In Lujan, the harm Congress sought to prevent would indeed have been redressed by the decree. The alleged violation was a procedural one - that is, a failure to require consultation with the Secretary of the Interior on the fact that the project threatened an endangered species. If we suppose that the injury-in-fact requirement is met, the redressability issue poses no further obstacle. If plaintiffs were injured 
by the failure to consult, then a decree ordering consultation would have redressed the harm. Of course, survival of the endangered species is not a necessary consequence of the requirement to consult. Perhaps the agencies would refuse to consult; perhaps removal of funding would not affect any species. But none of this is relevant. For purposes of redressability, a requirement of consultation must merely affect incentives in the statutorily required way.

On this point, Lujan is self-contradictory, and the internal contradiction helps show why redressability should have presented no problem. The Court acknowledged (without any real explanation) that in some cases involving procedural violations, plaintiffs need not show redressability. The Court stated that " $[t]$ his is not a case where plaintiffs are seeking to enforce a procedural requirement the disregard of which could impair a separate concrete interest of theirs . . ."204 and added in a crucial footnote: "The person who has been accorded a procedural right to protect his concrete interests can assert that right without meeting all the normal standards for redressability and immediacy."205

As noted, the Court did not explain this conclusion; I try to do so below. ${ }^{206}$ But if plaintiffs need not meet the normal standards for redressability for procedural violations, it follows that plaintiffs in $\mathrm{Lu}$ jan itself need not have met the normal standards for redressability. Indeed, under this reasoning, redressability need not be shown in a wide range of cases in which a plaintiff contends that the executive branch has failed to comply with a procedural requirement imposed by law. ${ }^{207}$

A contrary conclusion would produce surprising results. It would mean that Article III imposed a constitutional obstacle to most ordinary administrative law cases. In the usual case, a litigant contends that an agency has failed to follow some procedural requirement - by holding inadequate hearings, failing to give notice, meeting with private people, or attending to a statutorily irrelevant factor. In all such cases, it might well be said, under the apparent standard in Lujan, that the redressability requirement has not been met. In such cases, it is

204. 112 S. Ct. at 2142.

205. 112 S. Ct. at 2142 n.7.

206. See infra text accompanying notes $280-81$.

207. Hence Allen v. Wright, 468 U.S. 737 (1984), and Simon v. Eastern Ky. Welfare Rights Org. [EKWRO], 426 U.S. 26 (1976), are incorrect if they are understood as redressability cases. They may be right, but only because of likely congressional instructions. Congress does not ordinarily allow one taxpayer to litigate the tax liability of another. This well-established background principle is probably the concern to which these cases legitimately respond. See EKWRO, 426 U.S. at 46 (Stewart, J., concurring). 
entirely "speculative" whether a decree in the defendant's favor will remedy the alleged injury. Lujan cannot be understood to say that these conventional cases have all of a sudden become nonjusticiable.

I will attempt to sort out these very complex issues below. ${ }^{208}$ For the moment, we should think of redressability as a crude device for determining whether Congress intended to confer a cause of action. ${ }^{209}$ When Congress has not spoken, the absence of redressability - understanding the injury in relatively concrete, personalized terms - may argue for the conclusion that the national legislature has not conferred standing on the plaintiff. This idea may be part of the prudential notion that standing will not be recognized for "generalized grievances."210 Certainly courts should not recognize standing when the injury, however characterized, will not be redressed by a decree in the plaintiff's favor. As an independent Article III requirement, however, the notion of redressability makes little sense in the cases under discussion.

\section{Citizen Suits}

By far the most important and novel holding in Lujan was that Congress cannot grant standing to citizens. The largest conclusion, also set out in Justice Scalia's 1983 Suffolk Law Review article, is that Article III requires a concrete, particularized, actual, or imminent injury in fact that also satisfies the causation and redressability requirements. This conclusion rested on the Court's own precedents, on the Take Care Clause, and on a particular understanding of Article III. ${ }^{211}$ I take these in order.

a. Precedents. The Court relied on two sets of cases. The first, from the 1920s and 1930s, rejected on standing grounds some odd constitutional challenges to governmental decisions. In Fairchild $v$. Hughes, 212 the Court dismissed a suit that challenged the process behind ratification of the Nineteenth Amendment; in Massachusetts $v$. Mellon, ${ }^{213}$ the Court did the same for a taxpayer suit challenging fed-

208. See infra text accompanying notes 280-82.

209. See Fletcher, supra note 15.

210. See Valley Forge Christian College v. Americans United for Separation of Church \& State, Inc., 454 U.S. 464, 475 (1982).

211. The Court did not address some of the staples of standing law: that injury in fact assures "concrete adversariness"; that it guards against collusive suits; that it ensures that suits will not be hypothetical or remote. The Court was wise not to emphasize these points, since they have nothing to do with standing. See Sunstein, supra note 15, at 1448.

212. 258 U.S. 126 (1922).

213. 262 U.S. 447 (1923). 
eral expenditures; in Ex parte Levitt, ${ }^{214}$ the Court dismissed an action challenging Justice Hugo Black's appointment to the Supreme Court.

None of these cases involved a congressional grant of standing. All involved constitutional claims. Following the discussion in Part I, I suggest that all of these cases are best understood as attempts to persuade the Court to create private rights of action under constitutional provisions, as in the 1971 case of Bivins v. Six Unknown Named Agents. ${ }^{215}$ In Bivins, the Court concluded that the Fourth Amendment implicitly creates a private right of action - that is, it implicitly authorizes people to bring suit for damages to vindicate their Fourth Amendment rights. ${ }^{216}$ But not every constitutional provision creates a private right of action. It seems especially implausible to say that constitutional provisions create such rights when the relevant duty runs to the public as a whole rather than to affected individuals. Under traditional standards, a law that creates a duty to the general public does not give rise to privately enforceable rights. ${ }^{217}$

Fairchild, Mellon, and Ex parte Levitt should be seen as suits attempting to create private rights of action under constitutional provisions that did not contemplate such actions. This understanding accords with the language of the opinions, which indeed suggests that the relevant constitutional provisions do not create private rights. Hence the words in Fairchild: "Plaintiff has [asserted] only the right, possessed by every citizen, to require that the Government be administered according to law and that the public moneys not be wasted. $\mathrm{Ob}$ viously this general right does not entitle a private citizen to institute in the federal courts a suit . . .."218

In thinking about these precedents, we may go a bit further. $A$ well-established view holds that courts should be reluctant to invoke constitutional provisions as a check on democratic processes. ${ }^{219} \mathrm{Ex}$ cept when absolutely necessary, constitutional adjudication should be

214. 302 U.S. 633 (1937).

215. 403 U.S. 388 (1971).

216. 403 U.S. at 395.

217. See, eg., Cort v. Ash, 422 U.S. 66, 78 (1975) (citations omitted) ("First, is the plaintiff 'one of the class for whose especial benefit the statute was enacted' . . ?"); J.I. Case Co. v. Borak, 377 U.S. 426 (1964).

218. 258 U.S. at 129-30. It follows that if Flast v. Cohen, 392 U.S. 83 (1968), is correct, it is because the Establishment Clause indeed provides a Bivins-type cause of action to restrain unlawful expenditures. Thus Justice Brennan's dissenting opinion in Valley Forge Christian College v. Americans United for Separation of Church \& State, Inc., 454 U.S. 464 (1982), directs attention to the right issue - the existence of a private right. 454 U.S. at 492 (Brennan, J., dissenting). I believe, however, that his favorable conclusion was incorrect in the particular case.

219. The classic discussion is Alexander M. Bickel, The Least Dangerous Branch (1962). 
avoided. Many of the justiciability doctrines - standing, ripeness, mootness, political questions - can be understood as an effort to exemplify the relevant "passive virtues." 220

Ideas of this sort were close to the heart of the jurisprudence of Justices Brandeis and Frankfurter, who were, as we have seen, the central figures behind the rise of standing limitations. However controversial these ideas may be to some, ${ }^{221}$ they are fully intelligible. But there is a huge difference between cases reflecting judicial reluctance to invoke the Constitution to challenge legislative outcomes and cases in which Congress, the national lawmaker, has explicitly created standing so as to ensure bureaucratic conformity with democratic will.

In the latter sort of case, considerations of democracy support the grant of standing. The democratic process has produced citizen standing, which it perceived as necessary to promote compliance with the democratic will as reflected in the governing statute. The normal notions of "passive virtues" have no role. Hence the cases from the 1920s and 1930s seem irrelevant to the issue in Lujan.

The second set of precedents relied on in Lujan consist of cases from the 1970s and 1980s, announcing the three Article III requirements. Some of these cases had the same form as the cases from the 1920 s and 1930s. They too involved efforts to persuade courts to create private rights of action under constitutional provisions. ${ }^{222}$ In the other cases, the Court was not dealing with an express congressional grant of standing. This is a crucial difference. If standing depends on positive law, decisions denying standing without an express grant are hardly authority for cases with an express grant. Indeed, in some of these cases the Court expressly suggested that such a grant could make a critical difference. ${ }^{223}$

On the basis of all these considerations, it seems clear that the result in Lujan has no firm support in the precedents. The issue of citizen standing had never been decided.

b. Article II and the Take Care Clause. The Court's second argument is that standing limitations for citizens are necessary in order to protect against intrusions on the President's power under the Take Care Clause. ${ }^{224}$ This is an extremely important claim. It links Justice

220. See id. at 111-98.

221. See Gerald Gunther, The Subtle Vices of the "Passive Virtues": A Comment on Principle and Expediency in Judicial Review, 64 ColUM. L. REV. 1 (1964).

222. See Valley Forge, 454 U.S. at 464; United States v. Richardson, 418 U.S. 166 (1974); Schlesinger v. Reservists Comm. to Stop the War, 418 U.S. 208 (1974).

223. See, e.g., Linda R.S. v. Richard D., 410 U.S. 614, 617 n.3 (1973).

224. Lujan, 112 S. Ct. at 2145. 
Scalia's Lujan opinion with his insistence elsewhere on a "unitary executive," one that is free from interference by others. 225 We may speculate that, on Justice Scalia's view, the notion of a "unitary executive" equally forbids citizen suits that allow judicial intrusions on the "Take Care" power and statutory initiatives that remove executive power from the President in favor of independent counsels. But what is the precise relationship between standing limitations and the President's power to take care that the laws be faithfully executed?

From its text and history, it seems clear that the Take Care Clause confers both a duty and a power ${ }^{226}$ and that it does indeed impose limits on what courts can do to the bureaucracy. The Take Care Clause confers a power insofar as it grants to the President, and no one else, the authority to oversee the execution of federal law. 227 The provision therefore carries implications for the perennial question of the President's power over the administration. It also suggests that oversight of bureaucratic implementation falls to the President, not to Congress or the courts.

But the Take Care Clause confers a duty insofar as it imposes on the President both a responsibility to be faithful to law and an obligation to enforce the law as it has been enacted, rather than as he would have wished it to be. It is for this reason that the standard administrative law case raises no issue under the Take Care Clause. If an object of regulation establishes that an agency has enforced the law in an unlawful way, the President has violated his duty under the Take Care Clause. A judicial decree to this effect raises no problem under that clause; it merely enforces the constitutional obligation in the constitutionally authorized way.

This point is not limited to cases involving regulated objects. If a regulatory beneficiary with standing persuades a court that the President is violating the law, and the court so holds, there is no constitutional difficulty. Imagine, for example, that the plaintiffs in Lujan had purchased their plane tickets and made plans to leave for the relevant countries on a certain date. The Lujan Court acknowledged that such circumstances would give rise to standing. ${ }^{228}$ If the plaintiffs pro-

225. See Morrison v. Olson, 487 U.S. 654, 727 (1988) (Scalia, J., dissenting).

226. See Arthur S. Miller, The President and Faithful Execution of the Laws, 40 VAND. L. REV. 389 (1987).

227. I do not mean to take a position on the complex issues raised by presidential displacement of administrative authority. For a discussion of these issues, see generally Peter $\mathrm{L}$. Strauss, The Place of Agencies in Government: Separation of Powers and the Fourth Branch, 84 CoLUM. L. REV. 573 (1984).

228. See Lujan, $112 \mathrm{~S}$. Ct. at 2138 . I put to one side the issue of redressability; it is irrelevant for present purposes. 
ceeded to win on the merits, no problem would arise under the Take Care Clause. A judicial decision for the plaintiffs would signal that the President had violated his constitutional command to respect and enforce the ESA as enacted.

We can thus conclude that the Take Care Clause poses no problems in suits by regulated objects, and also no problem in suits by regulatory beneficiaries, even if they are requiring the executive to enforce certain laws against his will. All of this suggests that the relationship between standing limits and the Take Care Clause is at best ambiguous - and in the end, I believe, nonexistent. If a court could set aside executive action at the behest of plaintiffs with a plane ticket, why does the Take Care Clause forbid it from doing so at the behest of plaintiffs without a ticket? Why do courts become "virtually continuing monitors of the wisdom and soundness of Executive action"229 if they hear claims of official illegality in the second class of cases?

These questions do not establish that there are no limits on standing. But they do raise doubts about the relevance of the Take Care Clause. In fact they suggest that the clause, however relevant it may be to many issues on administrative law, is irrelevant to the question of standing.

Lujan seems to be built in key part on the idea that citizen standing - like other legislative interference with the President's power to execute the law ${ }^{230}$ - is unacceptable under Article II. Indeed, many of the recent standing cases might be thought to be Article II cases masquerading under the guise of Article III; we may even say that the Article II tail is wagging the Article III dog. But the conflation of Article II and Article III concerns has led to serious confusion. If a plaintiff with a plane ticket can sue under the ESA without offense to Article II, then it makes no sense to say that Article II is violated if a plaintiff lacking such a ticket initiates a proceeding. Beneficiary standing poses no Article II issue. The two articles raise quite different concerns; they should be analyzed separately.

The Court's answer, set out in a brief passage, appears to take the following form. It is one thing for judges to protect "individual rights." Courts can properly engage in this task, which is uniquely theirs. But it is another thing to protect "public rights that have been legislatively pronounced to belong to each individual who forms part of the public."231 In the end, however, this argument seems to have

229. 112 S. Ct. at 2145.

230. See Bowsher v. Synar, 478 U.S. 714 (1986); INS v. Chadha, 462 U.S. 919 (1983); Buckley v. Valeo, 424 U.S. 1 (1976).

231. Lujan, 112 S. Ct. at 2145. 
little to do with the Take Care Clause. Instead, it must rest on the understanding that Article III places a substantive limitation on what sorts of harms can count as legally cognizable injuries.

That leaves the question of the content of the limitation. If we supplement the cryptic passages in Justice Scalia's Lujan opinion with the fuller ones in Judge Scalia's Suffolk Law Review essay, we can offer some speculation. Perhaps individual rights count as such only when they are minority rights - when they are not widely shared. I will return to this point below. ${ }^{232}$ For the moment let us explore the question of substantive limits on congressional power to create causes of action.

c. Article III. In the end the best defense of Lujan must be that Article III allows federal courts to assume jurisdiction only when the plaintiff has a certain sort of interest. The core of the argument appears in Justice Scalia's 1983 article: Cases involving the requisite interests comport with "an accurate description of the sort of business courts had traditionally entertained, and hence of the distinctive business to which they were presumably to be limited under the Constitution."233 The statement is surprisingly casual. No historical argument is offered for the claim about the traditional "sort of business." Moreover, the word "presumably" takes the place of a complex historical argument.

As a matter of history, we have seen that Scalia's claim is not sound; in fact, it is baseless. As discussed in Part I, courts had "traditionally entertained" a wide variety of suits instituted by strangers. ${ }^{234}$ Neither English nor American practice supports the view that stranger suits are constitutionally impermissible. There is no evidence that Article III was designed to forbid Congress from entertaining such suits. On the contrary, the practice of the early Congress - freely creating the qui tam and informers' action without a hint of constitutional doubt - suggests that there were no limits on congressional creation of standing.

The absence of a firm basis for Lujan in constitutional text or history should probably be decisive against the Court's reasoning. If the text and history are compatible with what Congress has done in creating citizen suits, courts have no warrant to intervene. To reach this conclusion, it is not necessary to linger over Justice Scalia's more abstract and speculative argument about the appropriate role of the

232. See infra text accompanying notes 240-57.

233. Scalia, supra note 1 , at $\mathbf{8 8 2}$.

234. See supra text accompanying notes 32-71. 
courts in a democracy, an argument that stems from political theory. But because that argument is obviously influencing the development of standing principles in the Supreme Court and elsewhere, it is worthwhile to address the argument here.

\section{Detour I: Justice Scalia's Conception of Standing}

In his 1983 essay, Justice Scalia argued that "courts need to accord greater weight than they have in recent times to the traditional requirement that the plaintiff's alleged injury be a particularized one, which sets him apart from the citizenry at large."235 Scalia acknowledged that this was "not a linguistically inevitable conclusion."236 The text of Article III does not suggest that a personal injury is necessary. But in his key statement, discussed above, Scalia defended the limitation on grounds of tradition..$^{237}$

Scalia explicitly claimed that "there is a limit upon even the power of Congress to convert generalized benefits into legal rights - and that is the limitation imposed by the so-called 'core' requirement of standing."238 A central concern is what Scalia describes the recent rise of the courts as "equal partners" with the legislative and executive branches. In his view, this unfortunate development is related to the law of standing. Thus Scalia suggests that "[t]he sine qua non for emergence of the courts as an equal partner with the executive and legislative branches in the formulation of public policy was the assurance of prompt access to the courts by those interested in conducting the debate."239 Unlimited standing gave people this prompt access, thus impairing the system of separation of powers in two ways: first, by providing more occasions for judicial review of executive action; second, by changing the timing of that review.

The core of Scalia's argument, however, lies elsewhere.

[T] he law of standing roughly restricts courts to their traditional undemocratic role of protecting individuals and minorities against impositions of the majority, and excludes them from the even more undemocratic role of prescribing how the other two branches should function in order to serve the interest of the majority itself. ${ }^{240}$

It is through this lens that Scalia offers the distinction with which I began this article. In the first class of cases, "an individual who is the

235. Scalia, supra note 1 , at 881-82.

236. Id. at 882.

237. See supra note 233 and accompanying text.

238. Scalia, supra note 1 , at 886 .

239. Id. at 893.

240. Id. at 894 (emphasis omitted). 
very object of a law's requirement or prohibition seeks to challenge it"; here, standing is simple. In the second class, "the plaintiff is complaining of an agency's unlawful failure to impose a requirement or prohibition upon someone else"; here the harm is "a majoritarian one."241

The central point in the analysis is that

[u]nless the plaintiff can show some respect in which he is harmed more than the rest of us ... he has not established any basis for concern that the majority is suppressing or ignoring the rights of a minority that wants protection, and thus has not established the prerequisite for judicial intervention. ${ }^{242}$

Thus, the "doctrine of standing . . . is an essential means of restricting the courts to their assigned role of protecting minority rather than majority interests." 243 Scalia urged that judges had been assigned this role by the Constitution, and also that the other role - the protection of majority interests - would be poorly executed by judges.

After all, judges are removed from political accountability and selected from a highly educated elite. This situation

is just perfect for a body that is supposed to protect the individual against the people; it is just terrible (unless you are a monarchist) for a group that is supposed to decide what is good for the people. Where the courts, in the supposed interest of all the people, do enforce upon the executive branch adherence to legislative policies that the political process itself would not enforce, they are likely (despite the best of intentions) to be enforcing the political prejudices of their own class. ${ }^{244}$

Scalia was alert to the concern that, without broad standing for beneficiaries, legislative enactments would be unlawfully underenforced within the bureaucracy. Indeed, he noted that statutes might get "lost or misdirected" in the executive branch; furthermore, he admitted that this was indeed the consequence of his proposal. ${ }^{245} \mathrm{But}-$ and this is the article's striking conclusion - this is "a good thing."246 Executive nonimplementation of statutes is part of a well-functioning democratic process, keeping law current with existing views. "Yesterday's herald is today's bore."247

This is a provocative and arresting argument, made in short compass. But it faces several difficulties. One problem is that the argu-

241. $I d$.

242. Id. at $894-95$.

243. Id. at 895 .

244. Id. at 896.

245. Id. at 897.

246. $I d$.

247. $I d$. 
ment is strikingly ahistorical. The article does not address the question whether the Framers actually had this conception of Article III. As we have seen, there is no evidence that they did. There is considerable evidence to the contrary.

A second problem is that the approach seems inconsistent with some of the most prominent aspects of Justice Scalia's own jurisprudence. Justice Scalia usually insists that judges should read constitutional provisions at a low level of generality and avoid infusing them with broad "values" of their own. In his view, such impositions increase the occasions for judicial invalidation of legislation. ${ }^{248}$ In this case, however, Scalia reads Article III broadly, invests it with general, controversial values, and ultimately recommends judicial invalidation of the outcomes of democratic processes. The theory of "minority rights" is after all a controversial theory of democracy, counselling courts to act in some cases but not in others. Let us assume that the argument is plausible, as it indeed appears to be. Should even a plausible theory of this kind be invoked in order to invalidate a law that is not inconsistent with the text and history of the Constitution?

There is a further problem. In a case of beneficiary or citizen standing, courts are not enforcing "executive branch adherence to legislative policies that the political process itself would not enforce."249 Instead, they are requiring the executive branch to adhere to the law, that is, to outcomes that the political process has endorsed. In Lujan, for example, the plaintiffs would have won only if they could have shown an unambiguous legislative judgment in their favor. ${ }^{250}$ Standing would produce "legislative policies that the political process itself would not enforce"251 only if courts systematically misinterpreted statutes. But this seems to be an unsupportable assumption.

In addition, it is hardly a good thing if agency implementation defeats legislative judgments. Suppose, for example, that the EPA decided that statutes calling for a form of cost-benefit balancing should be construed not to allow consideration of costs, and thus to require a kind of environmental absolutism. Would it be plausible to say that this is "a good thing," so long as the agency, supervised as it is by the President, had so concluded? Surely not. Agency rejection of con-

248. See Planned Parenthood v. Casey, 112 S. Ct. 2791, 2884-85 (1992) (Scalia, J., dissenting); Harmelin v. Michigan, 111 S. Ct. 2680 (1991); Michael H. v. Gerald D., 491 U.S. 110, 112 (1989) (plurality opinion of Scalia, J.).

249. Scalia, supra note 1 , at 896.

250. Cf. Chevron USA v. NRDC, 467 U.S. 837 (1984) (noting that EPA regulations under Clean Air Act would not be set aside unless such regulations were contrary to the express intent of Congress or based on an unreasonable interpretation of the statute).

251. Scalia, supra note 1 , at 896. 
gressional enactments, even if motivated by the President himself, is inconsistent with the system of separation of powers.

There are of course important political constraints on administrative behavior, and an understanding of those constraints is a valuable part of administrative law. ${ }^{252}$ Moreover, the power of the executive to temper legislative enactments is indeed an important aspect of democratic government. The President can appropriately exercise this power in many areas, including prosecutorial discretion, interpretation of ambiguities, incremental policymaking, and not-so-incremental judgments when Congress has spoken ambiguously. But the executive is not normally empowered to violate the law through enforcement activity in violation of the boundaries set by Congress. Justice Scalia cannot be taken to argue in favor of the "updating" that occurs when the President implements a law in such a way as to rewrite it.

To bring this problem closer to the standing issue, suppose that an agency decides that the ESA should not be applied to American activities in foreign nations, when in fact Congress plainly intended that the ESA should apply abroad. Is this a good thing? On the contrary, it is a violation of democratic aspirations and (more relevant still) of the system for national lawmaking set up by Articles I and II of the Constitution. If agency enforcement beyond that intended by Congress is not "a good thing," even where the agency responds to political pressures, it is not "a good thing" where an agency undertakes a pattern of enforcement that violates congressional will through abdication or failure to act. Asymmetry on this point would simply translate judicial antipathy to regulation into administrative law. The foreclosure of standing cannot plausibly be defended as a means of allowing the bureaucracy to implement the law in a manner that conflicts with the governing statute.

Let us turn, finally, to Justice Scalia's argument from democratic theory, referred to briefly in Lujan itself. ${ }^{253}$ That argument rests on a distinction between minority and majority interests. The distinction between regulatory objects and regulatory beneficiaries, for purposes of standing, is said to rest on this prior distinction, which is itself said to be well adapted to the special role of courts in the American legal system. "Objects" represent a minority whose interests require judicial protection; "beneficiaries" represent a majority who can protect their concerns through the political process. But there are two problems with this argument. The first is that it does not justify a

252. See R. Shep Melnick, Administrative Law and Bureaucratic Reality, 44 ADMIN. L. REV. 245 (1992).

253. See Lujan, 112 S. Ct. at 2145. 
distinction between the objects and beneficiaries of regulation. The second is that it turns on an inadequate conception of the workings of American democracy.

Suppose we agreed that courts should not protect majority interests through administrative law. The result would be to jeopardize standing for many objects of regulation, not merely for beneficiaries. Often the objects of regulation are indeed majority interests. A regulation might, for example, affect a large number of companies at once, and in the process impose costs principally on consumers, which is to say on nearly all of us. Majorities are affected even when "objects" are at risk. But objects are not therefore to be deprived of standing, at least not without wreaking havoc on traditional administrative law. Indeed, the objects of regulation are not systematically more likely to be "majorities" than the beneficiaries. If we were to build our theory of standing on majority status, we must rethink standing in important ways - but not in the ways recommended by Justice Scalia. The majority-minority distinction is too crude a basis for distinguishing beneficiaries from objects.

Now let us turn to the workings of American democracy. Justice Scalia's argument seems to be that courts are well-suited to protecting minorities, which cannot protect themselves through the democratic process, whereas they are in poor position to protect majorities, whose natural forum is the democratic process. The politically responsive institution is in turn the executive branch.

But this argument is too simple. Some minorities are especially well-organized and do indeed have access to the political process, including the executive branch. The point is well documented.254 At least sometimes, regulated industries are a prominent example. But they are not therefore to be deprived of standing.

Moreover, some majorities are so diffuse and ill-organized that they face systematic transaction costs barriers to the exercise of ongoing political influence. This point is well documented in the area of environmental protection and elsewhere. ${ }^{255}$ The citizen suit is designed as a corrective. ${ }^{256}$ Essentially, this cause of action reflects the congressional judgment that some interests, including those of majorities, are so diffuse and unorganized that they require judicial protection in the implementation process. Congress' judgment to this effect

254. See supra note 99.

255. See supra note 100 and accompanying text.

256. See generally the analysis in Burton A. Weisbrod, Conceptual Perspective on the Public Interest: An Economic Analysis, in Public INTERest LAW 4 (Burton A. Weisbrod et al. eds., 1978). 
receives distinguished support from a significant body of empirical and analytic literature. ${ }^{257}$ Even if judges do not agree with that judgment, they should not foreclose the cause of action in the name of the Constitution.

I conclude that Justice Scalia's essay does not justify the view that Article III forbids the citizen suit. If Congress has chosen to rely on the citizen suit, courts should not foreclose that choice.

\section{Detour II: The Citizen Suit and the Administrative State}

To make a full evaluation of Lujan, a good empirical picture of the citizen suit would be valuable. What effect does the citizen suit have on the real world? Is it a valuable instrument of environmental and regulatory policy? How many citizen suits have merit? Does the citizen suit produce greater compliance with the law or better regulatory policy? In how many cases does the citizen suit facilitate standing, or simplify standing issues, compared to a requirement of injury in fact? The answers to such questions may not help with the constitutional issue. But they will aid in an assessment of whether the demise of citizen suits is an important event for administrative law.

Unfortunately, we have only the most preliminary of answers to these questions. In the early period of the citizen suit, exceptionally few plaintiffs filed such actions. ${ }^{258}$ Advocates of this form of enforcement were both surprised and greatly disappointed. But recent years, starting with 1983, have seen greater activity, especially under the Clean Water Act. ${ }^{259}$ Between 1984 and 1988 (when the EPA ceased collecting data on citizen suits), there were over 800 notices of intent to sue under that Act. ${ }^{260}$ The government was the defendant in 165 of these suits. Plaintiffs have won a large number of citizen cases under the Clean Water Act. ${ }^{261}$ Indeed, plaintiffs readily prevail under the

257. See, e.g., Richard B. Stewart, The Reformation of American Administrative Law, 88 HARV. L. REV. 1667, 1682-87 (1975).

258. See Adeeb Fadil, Citizen Suits Against Polluters: Picking Up the Pace, 9 Harv. Envtr. L. REv. 23, 29 (1985); David A. Feller, Private Enforcement of Federal Anti-Pollution Laws Through Citizen Suits: A Model, 60 Denv. L.J. 553, 564-65 (1983).

259. Barry Boyer \& Errol Meidinger, Privatizing Regulatory Enforcement: A Preliminary Assessment of Citizen Suits Under Federal Environmental Laws, 34 BuFF. L. REv. 833, 868-69 (1985). This study shows the following pattern under the Clean Water Act: one suit in 1978; eight in 1979; four in 1980; six in 1981; 16 in 1982; 62 in 1983; and 26 in the first four months of 1984. Id. at 869.

260. See Michael S. Greve, The Private Enforcement of Environmental Law, 65 TUL. L. REV. 339,353 (1990).

261. See id. at 355. For discussion of the reasons why the number of citizen suits under the Clean Water Act have increased, see Robert F. Bloomquist, Rethinking the Citizen as Prosecutor Model of Environmental Enforcement Under the Clean Water Act, 22 GA. L. REv. 337 (1988); Boyer \& Meidinger, supra note 259; Sean Connelly, Congressional Authority to Expand the Class 
Clean Water Act, apparently because some of the statutory provisions speak quite plainly and mandate unambiguous action. ${ }^{262}$

Post-Lujan, most environmental suits will be able to go forward under the injury-in-fact requirements. An environmental organization will typically be able to find a member who has the requisite injury. ${ }^{263}$ But the need to show an injury will complicate such suits, and some occasions will arise when no plaintiff can be found. Moreover, regulatory cases will arise in which the insistence on an actual injury, as understood in Lujan, will bar the action altogether. I discuss this possibility in Part III.

There is good reason to believe that the citizen suit has indeed helped bring about greater administrative compliance with law. But there is no reason to think that the citizen suit is a fundamental part of modern regulatory reform. I offer a brief account of a long story here. ${ }^{264}$

In its current form, the citizen suit should be seen as part and parcel of a largely unsuccessful system of command-and-control regulation. Under this system, Congress entrusts agencies with the job of issuing a massive number of highly centralized, rigid, and often draconian regulatory requirements. It should be no surprise that agencies are often unable to undertake their legally required tasks, especially in view of the fact that they infrequently receive the necessary resources. The citizen suit is part of a complex system in which Congress delegates difficult or even impossible tasks, appropriates inadequate resources, imposes firm and sometimes unrealistic deadlines, ${ }^{265}$ and enlists courts and citizens in order to produce compliance. ${ }^{266}$ The system may well find explanation in terms of the self-interest of elected representatives. ${ }^{267}$ Credit-claiming for apparently aggressive regula-

of Persons With Standing to Seek Judicial Review of Agency Rulemaking, 39 ADMIN. L. REv. 139 (1987); Fadil, supra note 258; David S. Mann, Comment, Polluter-Financed Environmentally Beneficial Expenditures: Effective Use or Improper Abuse of Citizen Suits Under the Clean Water Act, 21 ENvTL. L. 175 (1991); James L. Thompson, Citizen Suits and Civil Penalties Under the Clean Water Act, 85 Mich. L. REv. 1656 (1987).

262. See Michael S. Greve, Private Enforcement, Private Rewards: How Environmental Citizen Suits Became an Entitlement Program, in EnVironmental Politics, supra note 137, at 109.

263. See infra Part III.

264. Parts of the longer versions can be found in Bruce A. ACKerman \& William T. Hassler, Clean Coal/Dirty Air (1981); Stephen Breyer, Regulation and Its ReFORM (1982); DAVID OsBorne \& TED GaEbler, REINVENTING GOVERnMENT (1992); SuNSTEIN, supra note 162 .

265. On this issue, see Melnick, supra note 161, at 252-55, 300-01.

266. See Richard B. Stewart, The Discontents of Legalism: Interest Group Relations in Administrative Regulation, 1985 WIS. L. REV. 655, 666-67.

267. See generally Daniel A. Farber, Politics and Procedure in Environmental Law, 8 J.L. 
tion can coexist with a range of real-world loopholes, helping industry to escape from government controls. But the public is often the loser.

In these circumstances, the citizen suit is probably best understood as a band-aid superimposed on a system that can meet with only mixed success. Instead of band-aids, modern regulation requires fundamental reform. Congress should replace the command-and-control system with more flexible, incentive-oriented measures. ${ }^{268}$ Instead of a continuing emphasis on judicial review, modern bureaucracy needs large-scale shifts introduced and implemented by legislators and administrators themselves. ${ }^{269}$ We should not, however, forget that bandaids can do some good. The citizen suit may serve as an effective if partial alternative to massive regulatory overhaul. In any case, the complex policy issues do not bear on the interpretation of Article III.

\section{E. Coda: What the Court Should Have Said}

From what has been said thus far, we can offer some brief general words about the law of standing and Lujan itself. With respect to standing in general, the key question is whether Congress (or some other relevant source of law) has created a cause of action. Without a cause of action, there is no standing; there is no case or controversy; and courts are without authority to hear the case under Article III.

This point suggests that the real source of current difficulty is Data Processing, which diverted attention from the relevant question of cause of action to the irrelevant question of injury in fact. So long as injury in fact was thought to be the issue that Congress itself had made relevant under the APA, the difficulty was only minor. But when an injury in fact became both a necessary and sufficient condition for standing, the area grew badly confused.

The result was that courts began to grant standing in cases in which it should have been denied, and to deny standing in cases in which it should have been granted. ${ }^{270}$ Worse, the Court viewed the

ECON. \& ORGANIZATION 59 (1992) (discussing the symbiotic relationship between legislators and environmental groups).

268. See SunSTEIN, supra note 162, ch. 3; Bruce A. Ackerman \& Richard B. Stewart, Reforming Environmental Law: The Democratic Case for Market Incentives, 13 CoLUM. J. ENVTL. L. 171 (1988); Sunstein, supra note 137.

269. This is the lesson of such diverse works as ACKERMAN \& HASSLER, supra note 264; Jerry L. Mashaw \& David L. Harfst, The Struggle for Auto SafeTy (1990); Ackerman \& Stewart, supra note 268; Melnick, supra note 161; Peter L. Strauss, Revisiting Overton Park: Political and Judicial Controls Over Administrative Actions Affecting the Community, 39 UCLA L. REv. 1251 (1992).

270. Thus, for example, the court granted standing in United States v. SCRAP, 412 U.S. 669 (1973), an environmental case in which the law student plaintiffs could not easily show a cause of action conferred by Congress. Standing should almost certainly have been denied in SCRAP, even if an injury in fact might have been found. 
standing issue through the wrong lens. An injury in fact is not required by Article III, and it is not sufficient for standing. ${ }^{271}$ Both history and principle show that people with "injuries in fact" may or may not have standing. The question is whether Congress has conferred a right to bring suit.

Under this view of the matter, Lujan was a relatively simple case. The first question was one of positive law: whether Congress had granted or denied standing to the plaintiffs. Congress' grant of standing resolved that issue. The grant created the relevant injury for Article III purposes. There was no need to start with injury in fact and redressability, or even to address these issues at all. And if it should be thought - contrary to the view presented here - that there are some Article III limits on legislative power to confer causes of action on citizens, those limits surely were not reached in Lujan. This was, after all, a case in which the plaintiffs claimed an intention to go to a place where allegedly unlawful government expenditures placed endangered species at risk. The Constitution did not forbid that action from going forward. The Lujan Court should not have discussed redressability; the congressional grant of standing disposed of the issue. If redressability was relevant, the Court should have said that the injury created by Congress - to prevent the U.S. government from threatening to produce extinction - would indeed have been redressed by a decree in the plaintiffs' favor. ${ }^{272}$

\section{The FUtURE}

Lujan settled some important questions. But it left many issues open, and it raised at least as many new ones. The future looks particularly murky in light of Justice Kennedy's concurring opinion, which refused to join the plurality on redressability, questioned any focus on the common law as the exclusive source of injury, and suggested relatively broad congressional power on the issues of injury and causation. $^{273}$

In this Part, I outline the settled and unsettled issues. I also suggest how some of the current puzzles should be resolved. The most important conclusions involve possible congressional responses to $\mathrm{Lu}$ jan. I suggest that the simplest and most effective response would be the creation of a bounty for successful citizen plaintiffs. Such a bounty

271. See Fletcher, supra note 15, at 223.

272. See infra text accompanying notes 307-10 (suggesting that the ESA should be thought to confer a property interest on citizens).

273. See supra text accompanying notes 188-93. 
would build directly on the qui tam and informers' actions, and it should not raise a constitutional problem in the aftermath of Lujan.

A more complex response would be for Congress expressly to create a property interest in the various regulatory "goods" that it wants to authorize citizens to protect. It might, for example, say that citizens generally have a beneficial interest in certain endangered species that are at risk from acts of the U.S. government. This somewhat adventurous strategy would have the advantages of building on common law notions of interest and injury and of forcing focused congressional attention on the precise nature of the rights at stake. It would also respond to some of the concerns in Justice Kennedy's concurrence. Despite its relative novelty, an approach of this sort should also be constitutional.

\section{A. Easy Cases: What Lujan Permits}

The Lujan opinion does not reject a number of cases in which courts have given standing to environmental plaintiffs. On the contrary, it expressly endorses many such cases, even when the plaintiff is complaining that the executive has taken inadequate action to enforce the law. To this extent, the invalidation of the citizen suit allows a good deal of room for private litigants - regulatory beneficiaries - to initiate proceedings against the executive branch. The case therefore introduces some uncertainty into the law, but it probably does not work any fundamental shift in the environmental area.

The Court thus makes clear that, if an environmental plaintiff can show that its members use the particular environmental resource that is at risk, standing is available. It follows, for example, that a citizen in New York could, post-Lujan, complain about the failure to enforce clean air or clean water requirements in New York. The Court suggests as much by invoking the Japan Whaling case ${ }^{274}$ to show that an environmental organization could complain of excessive whale harvesting when the "whale watching and studying of their members w[ould] be adversely affected by continued whale harvesting."275 The Court also says that a citizens' council has standing to bring suit to challenge environmentally harmful construction in the area where its members live. ${ }^{276}$

274. Japan Whaling Assn. v. American Cetacean Socy., 478 U.S. 221 (1986).

275. Lujan, 112 S. Ct. at 2143 n.8 (endorsing standing in Japan Whaling, 478 U.S. at 230-31 n.4).

276. 112 S. Ct. at 2143 n.8 (endorsing standing in Robertson v. Methow Valley Citizens Council, 490 U.S. 332 (1989)). 
It also remains clear that some procedural injuries can produce standing under Article III. The Court writes:

This is not a case where plaintiffs are seeking to enforce a procedural requirement the disregard of which could impair a separate concrete interest of theirs (e.g., the procedural requirement for a hearing prior to denial of their license application, or the procedural requirement for an environmental impact statement before a federal facility is constructed next door to them). ${ }^{277}$

A citizen can thus complain about a failure to prepare an environmental impact statement (EIS) even though it is "speculative" whether the statement will cause the project to be abandoned. 278

Standing remains available in all cases under the National Environmental Policy Act (NEPA) ${ }^{279}$ whenever plaintiffs can show that the project, if completed, would adversely affect their interests. A concrete injury of this kind is sufficient even if ordinary redressability cannot be shown. "The person who has been accorded a procedural right to protect his concrete interests can assert that right without meeting all the normal standards for redressability and immediacy."280

It is clear that the Court believes this; but, as noted above, it is not clear why the Court does so. If Article III requires redressability, most NEPA suits indeed seem unconstitutional. In the typical NEPA action, there is no assurance that completion of an adequate EIS would have any consequence at all for the plaintiffs. One might well think, as the government urged in Lujan, that NEPA suits frequently violate Article III.

But as the Lujan Court appears to acknowledge, this would be an odd and far-reaching conclusion. It is almost always the case that procedural rights have only speculative consequences for a litigant. If a judge is found to have ruled in favor of party $A$ after taking a bribe from party $A$, it remains speculative whether an unbiased judge would have ruled for party $B$. Does party $B$ therefore lack standing? Or suppose that an administrator is found to have violated the Administrative Procedure Act by promulgating a regulation without first publishing it for comment in the Federal Register. It is entirely speculative whether compliance would make any difference to the complainants. The Lujan Court, however, does not want the redressability requirement to bar standing in such cases.

Perhaps the Court is endorsing Justice Kennedy's suggestion that

277. 112 S. Ct. at 2142.

278. 112 S. Ct. at $2142-43$ n.7.

279. 42 U.S.C. $\S \S 4321-70$ (1988).

280. Lujan, 112 S. Ct. at 2142 n.7. 
"Congress has the power to define injuries and articulate chains of causation that will give rise to a case or controversy where none existed before."281 More deeply, however, I think that the Court's conclusion on this point exemplifies several of the problems associated with the whole notion of redressability. A procedural right is created, not because it necessarily yields particular outcomes, but because it structures incentives and creates pressures that Congress has deemed important to effective regulation. The same is true for the sorts of interests at stake in the ESA and in many other environmental statutes. Congress is attempting not to dictate outcomes but to create procedural guarantees that will produce certain regulatory incentives. Redressability in the conventional sense is irrelevant.

This point might well have arisen in Lujan itself. Even though it did not, the opinion makes clear that procedural harms remain cognizable when ordinary injuries are involved, despite the absence of redressability.

\section{B. Easy Cases: What Lujan Forecloses}

Thus far I have explained the types of suits Lujan has left untouched. But it is equally clear that Lujan forecloses "pure" citizen suits. In these suits, a stranger with an ideological or law-enforcement interest initiates a proceeding against the government, seeking to require an agency to undertake action of the sort required by law. Many environmental statutes now allow such actions, and plaintiffs have brought many suits of this kind. Under Lujan, these suits are unacceptable. Congress must at a minimum "identify the injury it seeks to vindicate and relate the injury to the class of persons entitled to bring suit." 282 If Congress has simply given standing to citizens, ${ }^{283}$ this requirement has not been met. The plaintiff must point to a concrete injury, not merely to a congressional grant of standing.

\section{Injury in Fact?}

The discussion thus far has focused to a large extent on changes in the law of injury in fact. Lujan extends this change, placing a renewed emphasis on the notion that the harm must be imminent and nonspeculative. This requirement will likely carry more weight than it has in the past. Before Lujan, requiring people to obtain a plane ticket or to make firm plans to visit the habitat of endangered species might

281. $112 \mathrm{~S}$. Ct. at 2146-47 (Kennedy, J., concurring).

282. 112 S. Ct. at 2147 (Kennedy, J., concurring).

283. See the provisions cited supra note 11. 
well have been unnecessarily formalistic. Now such actions are apparently required. But this is not a fundamental revision of previous law. The celebrated $S C R A P$ case $^{284}$ is probably a relic. But on that point, the handwriting had been on the wall a long time, and, if the analysis thus far is correct, there is no reason to mourn for $S C R A P$, in which Congress had not conferred a right to bring suit.

Harder questions could arise in consumer cases, which play a large role in contemporary administrative law. Suppose, for example, that the government imposes on automobile manufacturers fuel economy requirements that are less stringent than the law requires. ${ }^{285}$ Typically, plaintiffs will argue that their injury consists of a diminished opportunity to purchase the products in question.286 After Lujan, standing becomes a difficult issue in such cases. A court might find that the plaintiffs lack a concrete or particularized interest. They are perhaps not readily distinguished from the public at large. There is an issue about speculativeness as well: perhaps the relationship between a consumer and a product that he allegedly wants is the same as the relationship between the Lujan plaintiffs and an endangered species, in the sense that in neither case is it clear that the injury will occur as a result of the complained-of government acts.

A consumer case of this sort may differ from Lujan, however, in the important sense that a consumer who complains of a diminished opportunity to purchase a product can very plausibly claim that he will in fact purchase that product. This claim is probably less speculative than that in Lujan. It is possible to discount an "intention" to undertake difficult foreign travel at an unspecified time; the intention may not show sufficient likelihood of harm. But it is harder to discount an intention to purchase a specified product, which usually applies to a single, simple transaction. The distinction suggests that, at least as Lujan stands, it does not significantly affect the standard consumers' action. In the automobile case, the key point is that a moreor-less sharply defined category of consumers is distinctly affected in a relatively nonspeculative way, and this is probably enough for standing. ${ }^{287}$

The same would be true in the standard broadcasting case, in

284. United States v. SCRAP, 412 U.S. 669 (1973).

285. This was the allegation in Center for Auto Safety v. NHTSA, 793 F.2d 1322 (D.C. Cir. 1986), and Center for Auto Safety v. Thomas, 806 F.2d 1071 (D.C. Cir. 1986), vacated per curiam, 810 F.2d 302 (D.C. Cir. 1987), reinstated per curiam, 847 F.2d 843 (D.C. Cir.) (en banc) (by an equally divided court), vacated per curiam, 856 F.2d 1557 (D.C. Cir. 1988).

286. See Center for Auto Safety v. NHTSA, 793 F.2d at 1332; Center for Auto Safety v. Thomas, 847 F.2d at 849.

287. But see Center for Auto Safety v. Thomas, 847 F.2d at 878 (Silberman, J., dissenting). 
which listeners or viewers in a defined area, or of defined programming, challenge an FCC decision that bears on their programming choices. ${ }^{288}$ If the FCC refuses to license a classical music station, there is a concrete injury, and it is sufficiently particularized under Lujan. The intention to listen to a station is not as conjectural as the travel intention at issue in Lujan.

Greater difficulties may arise in some similar actions, as when, for example, consumers challenge an FDA or EPA regulation allowing carcinogens to be added to food.289 There may be serious standing problems in such cases. A person complaining about such a regulation might be said to be suffering an injury that is speculative or generalized. This is especially likely insofar as the injury is characterized as an actual incidence of cancer. It is extremely speculative to suggest that the introduction of carcinogenic substances into food additives will produce cancer in particular human beings.

The issue becomes harder if the injury is characterized as a greater risk of cancer. In that event, the injury is less speculative; but it is unclear that it is sufficiently particularized. On Justice Kennedy's view, there is probably enough for standing, for he insisted that standing can exist even if the injury is very widely shared. ${ }^{290}$ This is indeed the correct view, because it is the most plausible conception of the injury that Congress sought to prevent. ${ }^{291}$ But the issue is now open.

\section{Redressability}

Because only four justices concluded that the redressability requirement had not been met in Lujan, the case probably offers no real lessons on that issue. After Lujan, the law of redressability thus remains as it was before: Extremely fuzzy and highly manipulable. It is manipulable, first, because there is no clear metric by which to decide whether it is "speculative" to say that a decree will remedy the plaintiff's injury. It is manipulable, second, because, as we have seen, whether an injury is redressable depends on how it is defined. If the injury in the Bakke case was defined as the right to attend law school, the redressability requirement was violated. If the injury in a standard environmental case is defined as the right not to suffer concrete personal health damage as a result of environmental harm, many environ-

288. See, e.g., Office of Communication of the United Church of Christ v. FCC, 359 F.2d 994, 1002 (D.C. Cir. 1967).

289. See Les v. Reilly, 968 F.2d 985 (9th Cir. 1992); Public Citizen v. Young, 831 F.2d 1108 (D.C. Cir. 1987).

290. Lujan, 112 S. Ct. 2130, 2146 (Kennedy, J., concurring).

291. See supra text accompanying notes $195-200$. 
mental plaintiffs will be unable to show redressability. If, however, the injury is defined as freedom from a certain risk of health damage, there is no problem of redressability. This indeed appears to be the way courts conventionally treat the issue.

Consider, for example, some of the regulatory cases described above. If an agency changes its policy for determining fuel efficiency, will prospective purchasers of fuel-efficient vehicles be affected? The answer is not clear. Perhaps manufacturers would simply pay civil penalties, rather than change their behavior. ${ }^{292}$ It is speculative whether government policies will change the policies of manufacturers soon enough to affect particular consumer choices. ${ }^{293}$ If the EPA refuses to allow carcinogens onto the market, perhaps the consumer will get cancer in any event; perhaps he will not get cancer whatever the EPA does. In fact, the EPA decision may well not make the difference in the life of any particular person. Standing might therefore be denied on grounds of redressability.

If we were to start afresh, the best way to handle the issue would be to say that the question of standing depends on whether Congress has authorized the plaintiff to bring suit. We should be asking whether the injury that Congress sought to prevent would likely be redressed by a favorable judgment. ${ }^{294}$ The redressability requirement might be understood as a crude way of asking that very question under the general rubric of "injury in fact." We might therefore try to answer the redressability question by characterizing the injury in the way desired by Congress, and then seeing if that injury would be removed by a decree in the plaintiff's favor. Through this route, the question of characterization could be resolved through legislative judgments, not judicial ones. And while the resulting issues of statutory interpretation will not always be simple, they raise the right questions.

\section{E. What Role Remains for the Citizen Suit?}

The status of the citizen suit is somewhat obscure after Lujan. At

292. See Center for Auto Safety v. NHTSA, 793 F.2d 1322, 1344 (D.C. Cir. 1986) (Scalia, J., dissenting).

293. See Center for Auto Safety v. Thomas, 847 F.2d at 870-72 (opinion by Buckley, J.).

294. The same point is urged in connection with redressability in Fletcher, supra note 15:

[T] he causation and redressability question is meaningful only at the level of determining whether a cause of action should exist for a certain group of plaintiffs under a particular statutory or constitutional provision .... [G]iven the different purposes of different statutory and constitutional provisions, some variation is entirely appropriate from one provision to another. ... The question is whether, under the statutory or constitutional provision at issue, the particular provision should be read to protect against the injury asserted by the kind of person who is seeking to bring suit.

Id. at 242-43. 
a minimum, we know that Congress cannot grant standing to people who have no personal stake in the outcome of an agency action. But Justice Kennedy, joined by Justice Souter, said that Congress "has the power to define injuries and articulate chains of causation that will give rise to a case or controversy where none existed before."295 This is a potentially crucial phrase. What does it mean? At a minimum, it means that Congress can create rights foreign to the common law. These include the right to be free from discrimination, ${ }^{296}$ the right to occupational safety, 297 indeed, the vast panoply of statutory rights going beyond common law understandings. It must also mean that Congress has the power to find causation, perhaps deploying its factfinding power, where courts would not do so.298 Justice Kennedy thus suggests that Congress can find causation and redressability even where courts would disagree. Perhaps courts will review such findings under a deferential standard.

This view would not change the outcome in Lujan. In that case, there was no injury in fact. But it might well make a difference in the several cases in which the Court has previously rejected standing on grounds of causation and redressability. Congress might well have the power to alter those outcomes.

Suppose, for example, that Congress found that efforts to produce desegregation were adversely affected by a grant of tax deductions to schools that discriminated on the basis of race. This finding might well call for a reversal of the outcome in Allen v. Wright. 299 Or suppose that Congress found that failure to attain national ambient air quality standards in New York had adverse health effects on the citizens of New York, New Jersey, Connecticut, and Pennsylvania. Perhaps courts would have to respect this finding.

The more difficult question involves constraints on Congress'

295. Lujan, 112 S. Ct. at 2146-47 (Kennedy, J., concurring).

296. See Havens Realty Corp. v. Coleman, 455 U.S. 363, 373 (1982); Trafficante v. Metropolitan Life Ins. Co., 409 U.S. 205, 212 (1972) (White, J., concurring). As noted above, the Havens Court found an injury to a "statutorily created right to truthful housing information," which it held sufficient for standing. 455 U.S. at 374. Effectively, Congress had created a kind of property interest in such information. The Lujan Court does not explain why Congress may not do the same for endangered species, or for the rainforest, or for clean air in an area in which one does not live. See supra text accompanying note 202; cf. United States Parole Commn. v. Geraghty, 445 U.S. 388, 404 (1980) (noting that a class action does not become moot after the named plaintiff's substantive claim has expired as the representative retains a "personal stake" in obtaining class certification).

297. See Occupational Safety and Health Act, 29 U.S.C. $\S 651$ (1988).

298. See generally Christopher Sprigman, Comment, Standing on Firmer Ground: Separation of Powers and Deference to Congressional Findings in the Standing Analysis, 59 U. CHI. L. REV. (forthcoming 1992).

299. 468 U.S. 737 (1984). 
"power to define injuries." Can Congress say that opportunity-type injuries are legally cognizable? Might Congress follow the Bakke strategy and conclude that standing exists in many cases involving increases in risks or attempts to alter incentives? Lujan provides no authoritative answer. But Justice Kennedy's concurrence suggests that Congress does possess power to define these events as injuries for purposes of standing. Justice Kennedy emphasized that standing need not be based solely on common law-like injuries; his concern was that, in creating the citizen suit, Congress had not even identified the injury it was attempting to redress. Congress can meet this concern by identifying injuries, building on the common law framework to recognize probabilistic, systemic, or regulatory harms. The decreased probability of injury, the grant of opportunities, and the provision of appropriate incentives are key goals of the regulatory state. It should not be difficult for Congress to connect these goals to the injuries it seeks to prevent. Nothing in Article III forbids this course, even after Lujan.

\section{F. Private Defendants}

Many citizen-suit provisions in the environmental laws give the citizen the option of initiating proceedings against the private defendant allegedly operating in violation of federal law. Formally, Lujan did not address this strategy because the case involved a governmental defendant. Does Lujan affect suits against private persons? The answer is unclear. We have seen that a large part of the Court's opinion relies on the fear that, without a particularized injury, courts will be displacing executive power under the Take Care Clause. This concern is entirely inapplicable when the executive is not even a party. ${ }^{300}$ On the other hand, if Article III does indeed require a personal stake, the identity of the defendant should not matter. A case in which a citizen initiates proceedings against a private defendant would indeed test the claim that the Take Care Clause is a major impetus behind the Lujan decision.

I have argued that this claim makes little sense. If so, and if Lujan remains good law, a citizen should not have standing to proceed against a private defendant unless he can show some kind of personal

300. A qualification is necessary here. When private people sue other private people to enforce federal statutory law, there is a lurking issue about private interference with the exercise of prosecutorial discretion, and hence with the President's "Take Care" power. But this issue surely does not have constitutional status. Parallel public and private remedies are most familiar to American law; they do not violate the Constitution. 
stake. After Lujan, the citizen-suit provisions are probably unconstitutional even when the defendant is a private citizen or corporation.

\section{G. Cash Bounties}

Perhaps Congress can respond to Lujan by granting cash bounties to citizen plaintiffs. Indeed, this possibility might produce some of the most important and difficult post-Lujan issues. If Congress wants to reinstate the citizen suit after Lujan, a cash bounty would be the simplest strategy. Indeed, an exceedingly short amendment to existing law, giving a bounty to all successful citizen plaintiffs, should be sufficient. For reasons that follow, the bounty should create an interest and hence standing. In this way, a system of bounties would fully overcome the post-Lujan doubts about the citizen suit. A bounty system would also be more straightforward than the principal alternative strategy now available to Congress, involving restructured property rights. ${ }^{301}$

A bounty system would have the important advantage of building on the clear historical precedents of qui tam and informers' actions, precedents that are firmly established in American law. ${ }^{302}$ To the extent that the citizen suit is a helpful device, ${ }^{303}$ Congress should be encouraged to take this step. At least where administrative inaction is both harmful and predictable, and where it cannot be prevented through more fundamental regulatory reform, ${ }^{304}$ a bounty system would make a great deal of sense. Indeed, the creation of a system of citizen bounties could well be a major step in administrative law.

\section{Private Defendants}

In the first case, Congress might allow citizens to proceed against polluters or others without requiring a conventional injury in fact, but with provision for a financial bounty to victorious citizen litigants. Does the bounty create the requisite personal interest or concrete stake?

In this context, Lujan is probably inapplicable by its own rationale. There is no risk that courts will usurp executive functions under the Take Care Clause. The executive is not a defendant. Not only is the executive not involved, but the plaintiff has a concrete interest in the form of the bounty. Standing seems perfectly appropriate. In fact, the

301. See infra text accompanying notes 307-10.

302. See supra text accompanying notes 59-67.

303. See supra text accompanying notes 136-37.

304. See supra text accompanying notes 265-69. 
Lujan Court seemed to invite this conclusion: "Nor, finally, is [this] the unusual case in which Congress has created a concrete private interest in the outcome of a suit against a private party for the government's benefit, by providing a cash bounty for the victorious plaintiff."305 The qui tam action and the informers' action ${ }^{306}$ seem to be decisive precedents in favor of this conclusion. In both of these actions, a bounty was provided, and it would be most adventurous to say that these arrangements violated Article III.

\section{Executive Defendants}

In the second case, Congress might give a cash bounty to litigants who have prevailed against the government. It might, for example, award $\$ 500$ to plaintiffs in cases involving environmental harms. It might even amend all current citizen-suit provisions in order to provide a cash bounty. A simple statute could accomplish this goal. Would this entail a different outcome from that in Lujan?

The answer is unclear. On the one hand, the executive remains a defendant, and the Lujan objection from the Take Care Clause remains. On the other hand, the existence of a cash bounty gives the plaintiff the equivalent of a personal stake in the outcome, just like a case in which she has a right to obtain damages from a common law tortfeasor. This personal stake is probably sufficient to create standing. Here the informers' action is a direct precedent.

The Take Care Clause, even as understood in Lujan, is likely to be held irrelevant where a bounty is at stake. According to the Court, the clause furnishes no objection in a case in which the plaintiff can show that the government's allegedly unlawful inaction impairs her enjoyment of some environmental asset. Hence the Take Care Clause is not a freestanding objection to suits of this general kind. It is called into play only in cases without a personal stake for the plaintiff. If a plaintiff can show that she stands to gain or lose from the outcome of the action, she is no longer interested only in "law enforcement for its own sake." She thus has standing to initiate the action.

If this analysis is correct, Congress has available a relatively simple corrective to Lujan if it believes that the decision will significantly undermine its regulatory goals. Existing statutes can be simply amended through the grant of a bounty to victorious citizen plaintiffs. No Article III problem would result from this initiative. If Congress wants to overcome Lujan, this is the best and simplest route. It would make

305. Lujan, 112 S. Ct. at 2143.

306. See supra text accompanying notes 59-67. 
the various citizen-suit provisions constitutional in cases in which $L u$ jan draws them into severe doubt.

\section{H. Redefined Property Rights}

I have criticized the injury-in-fact test on the ground that it undermines Congress' power to create property rights where they had not existed before. In Lujan, the plaintiffs might well have asserted that the conferral of a cause of action amounted to the creation of a form of property. Justice Kennedy had an answer to this claim: "Congress has the power to define injuries and articulate chains of causation that will give rise to a case or controversy where none existed before." 307 But here Congress has refused to "identify the injury it seeks to vindicate and relate the injury to the class of persons entitled to bring suit."308 Apparently, plaintiffs had no property right under the ESA, because Congress failed explicitly to define the relevant injury when it provided for citizen suits.

Suppose, then, that Congress attempts to create a citizen suit in the following way. It announces, first, that all Americans have a kind of property right - a tenancy in common - in some environmental asset. The asset might be clean air anywhere in the country, or pristine areas, or the continued existence of endangered species in the United States or abroad. If this seems odd, we might note that Congress could surely create property rights in unowned land within the United States; to the extent that such rights do not interfere with the claims of a competing sovereign, Congress can create them with respect to unowned land outside our territorial borders. ${ }^{309}$ And surely Congress' capacity to create property rights is not limited to land. If Congress thus defines property rights and injuries and creates a correlative cause of action, has it acted appropriately and met Justice Kennedy's concern?

The answer would seem to be affirmative. The advantages of express legislative creation of a property right are that it would build on common law understandings and produce more focused congressional deliberation on the nature of the interest it is creating. The citizen suit

307. Lujan, 112 S. Ct. at 2146-47 (Kennedy, J., concurring).

308. 112 S. Ct. at 2147 (Kennedy, J., concurring).

309. The point may seem odd, but we can imagine an example. Suppose that an area in Argentina produces medicines especially beneficial to Americans. Suppose that the activities of private American companies in Argentina threaten to industrialize that area and thus to eliminate its medicinal capacities. Congress might respond by forbidding these activities and by creating a property right in all Americans, operating only against other Americans, to the continued productivity of the area. This could not possibly raise a constitutional issue, or even a problem of international law. 
has become a relatively automatic part of environmental law, with little legislative attention to its nature and consequences. If the citizen suit is in fact intended to give all citizens the equivalent of a beneficial interest in environmental quality, it may well be desirable to focus congressional attention on exactly that question. And if Congress concludes that it seeks to create this kind of property, there should be no constitutional problem.

Indeed, the case would seem to be very close to Havens Realty, ${ }^{310}$ discussed above. If there is a difference, it is that, in the cases under discussion, Congress has created a tenancy in common with respect to a collective good - that is, property that is jointly owned. In Havens Realty, by contrast, the property right could be held by individuals rather than many people at once.

Under Justice Scalia's conception of standing, this distinction would make a difference. In the collective good case, unlike in Havens Realty, we are hardly dealing with "minorities." Majorities may have less need for the citizen suit. But this conception of standing faces many problems, as elaborated above. In any event, Justice Kennedy clearly disagrees on this point. His opinion plainly says that standing is not to be denied simply because many people are adversely affected.

If all this is correct, some of the most interesting developments in the law of standing may arise when Congress is explicit in its intention to create new forms of property adapted to the problems and aspirations of modern regulation. If Congress creates property rights in environmental assets of various sorts, and grants correlative causes of action, it should be able to overcome the strictures of Lujan. Faced with such an enactment, the Court would not be dealing with a "citizen suit" at all. Instead it would be faced with a suit brought by property holders equipped with causes of action; and it would be odd if congressional initiatives in this direction would be held inconsistent with Article III.

\section{CONCLUSION}

At least in general, standing depends on whether any source of law has created a cause of action. To a large extent, that question is for congressional resolution. Congress can create standing as it chooses and, in general, can deny standing when it likes. ${ }^{311}$ As an abstraction

310. Havens Realty Corp. v. Coleman, 455 U.S. 363 (1982); see supra notes 125-29 and accompanying text.

311. The foreclosure of standing might, however, raise problems under Article III and the Due Process Clause. On Article III, see Richard H. Fallon, Of Legislative Courts, Administrative Agencies, and Article III, 101 HARV. L. REv. 915 (1988); on due process, see Yakus v. United 
independent of what the law says, an injury in fact is neither a necessary nor a sufficient condition for standing. Indeed, the notion of injury in fact is a form of Lochner-style substantive due process. It assumes that there can be a factual inquiry into "injury" independent of evaluation and of legal conventions. There can be no such law-free inquiry. It is a conceptual impossibility, indeed a form of metaphysics.

Despite the holding of Lujan, Congress should be permitted to grant standing to citizens. The text and history of Article III provide no support for judicial invalidation of congressional grants of citizen standing. On the contrary, England, the American colonies, and early Congresses all granted standing to strangers. No one suggested that this practice violated the Constitution. The Lujan Court's unprecedented invalidation of a provision for citizen standing has no basis in Article III. The Court should not have reached its important conclusion without investigating the relevant history, and the odd evolution of standing doctrine, in much more detail.

Lujan answers a long-unresolved issue; but it leaves a number of other significant questions unanswered. I have tried to describe how they might be resolved. It seems clear that citizen-suit provisions are now impermissible in the absence of a showing of injury in fact. But Lujan permits environmental actions whenever plaintiffs can show that environmental degradation will affect their geographical area in the form of dirtier air, dirtier water, or inferior aesthetics. Many suits by regulatory beneficiaries will thus remain viable.

Perhaps most important, Congress probably retains a relatively simple mechanism by which to accomplish the purposes that underlie current provisions for citizen actions. Certainly it can grant citizens standing against private defendants so long as it allows some kind of bounty for a victorious lawsuit. Almost certainly, Lujan permits Congress to allow citizens to bring suit against the government for insufficient regulatory action, if a bounty is made available in the event of success.

Most intriguingly, Justice Kennedy's concurring opinion leaves open the possibility that Congress has the power to create quite novel property interests, to grant those interests to many people or even to citizens, and to confer standing to enable people to vindicate those interests. It may be that, in cases raising this issue, we will see the ultimate depth of the Court's commitment to Lujan's odd adventure in substantive due process.

States, 321 U.S. 414, 431-33 (1944). The Constitution might also limit Congress' power to grant standing to people attempting to vindicate constitutional rights. See Fletcher, supra note 15, at 278-79. 